\title{
Por qué los ricos siempre siguen siendo ricos (pase lo que pase, cueste lo que cueste)
}

\author{
José Gabriel Palma
}

Determinar las leyes que regulan [la distribución del ingreso] entre los rentistas, los capitalistas y los trabajadores ... es el principal desafío de la economía política (David Ricardo)

La desigualdad es una opción [entre alternativas perfectamente factibles] (Joseph Stiglitz) No hay nada que muestre mejor quienes somos en realidad, que las opciones que tomamos

(Jean-Paul Sartre)

La comodidad de los ricos depende de la abundancia de pobres (Voltaire)

\section{Resumen}

Este artículo retoma la tradición ricardiana de entender la distribución del ingreso como la articulación de un conflicto "antagónico", con multiplicidad de agentes y luchas, en que la historia, la política y las instituciones importan tanto como los "fundamentos" económicos. Por pertenecer a "lo político", en este conflicto no hay soluciones meramentelógicas, sino opciones en un escenario de equilibrios múltiples. En mercados desregulados este conflicto favorecería la supremacía de las rentas no productivas (en especial las de "ineficiencia"), en desmedro de las utilidades operativas, afectando la inversión y el crecimiento de la productividad. Además, las instituciones disfuncionales tendrían "capacidad para persistir", transformando el régimen de dominación en un "proceso estacionario": los impactos desestabilizadores solo tendrían efectos temporales. Para esto, cuando en democracia la oligarquía latinoamericana limita el cambio y debilita al Estado imponiendo amarres constitucionales buchanianos, rediseña sus estrategias distributivas y absorbe elementos de ideologías opuestas para mantener la hegemonía de la suya.

\section{Palabras clave}

Distribución del ingreso, desigualdad, coeficiente de Palma, ideología, cierre de brechas "al revés", persistencia institucional, neoliberalismo, nueva izquierda, pobreza, Europa occidental, países emergentes de Asia, América Latina, Chile

\section{Clasificación JEL}

D31, E12, N36, P16

Autor

José Gabriel Palma es Doctor en Economía por la Universidad de Oxford y en Ciencias Políticas por la Universidad de Sussex. Ha sido Profesor de Econometría, Macroeconomía, Desarrollo e Historia Económica en la Facultad de Economía de la Universidad de Cambridge desde 1981. También es Profesor de Economía (a tiempo parcial) en la Universidad de Santiago. Su investigación se centra en América Latina, Asia, Sudáfrica, Europa y los Estados Unidos desde las reformas neoliberales, la distribución del ingreso, la desindustrialización, las crisis financieras y la historia económica de América Latina. Correo electrónico: jgp5@cam.ac.uk. 


\section{Introducción ${ }^{1}$}

En este artículo se estudia la compleja e intrigante cuestión de por qué los ricos tienden a seguir siendo ricos, sin importar la voluntad del resto de la sociedad. Para esto se retoma la tradición ricardiana de entender la distribución del ingreso como el resultado de la articulación del conflicto entre los rentistas, los capitalistas y los trabajadores (y ahora también la burocracia), donde la historia, la política y las instituciones importan tanto como los "fundamentos" económicos. Esto es, de entenderla como la articulación de un conflicto en el cual hay una multiplicidad de agentes y luchas. Esta visión de la desigualdad se contrapone tanto con la neoclásica, y su interacción un tanto mecánica de puros fundamentos, como con aquella tradición de la izquierda donde hay solo un conflicto (la lucha de clases), y solo dos agentes (capital y trabajo) - y donde esa lucha se articula en un marco teleológico-.

Desde nuestra perspectiva ricardiana, el conflicto distributivo es por naturaleza "antagónico", por lo que en lo fundamental pertenece a la arena de "lo político", donde no hay soluciones meramente lógicas (Laclau y Mouffe, 2011). Es una historia de opciones reales en un escenario de equilibrios múltiples (Palma, 2019a). Además, como en esta tradición ricardiana el eje analítico está en la distinción entre las "rentas" y las "utilidades operativas", en una economía sin un Estado fuerte e inteligente (en el sentido de Mazzucato (2018)) y con mercados desregulados, este conflicto favorecería la supremacía de las rentas fáciles y no productivas (incluidas las de "ineficiencia", esto es, las que retardan el crecimiento pues nacen de la manipulación del mercado) en desmedro de las utilidades operativas, afectando la inversión y el crecimiento de la productividad. Esto se potenciaría en economías ricas en recursos naturales con apropiación privada de dichas rentas, pues como ellas se captan por completo en la etapa inicial extractiva, los mercados desregulados (como el de Chile) solo incentivarían lo extractivo y no la diversificación productiva. Esta es la principal lección del "modelo nórdico": la industrialización basada en dichos recursos requiere de un Estado que coordine la inversión en esta dirección. De lo contrario, aquellos con preferencias rentistas tendrían las de ganar en lo distributivo y las instituciones disfuncionales tendrían gran "capacidad de persistir". Esto es particularmente relevante en el análisis de América Latina desde las reformas neoliberales y su desaceleración del crecimiento de la productividad (el promedio de la región ha estado prácticamente estancado desde 1980 (The Conference Board, 2020)). Esta transferencia de ingresos dentro de la élite capitalista a favor de rentistas y en contra de empresarios impactaría la inversión, la absorción tecnológica y la innovación².

Para Ricardo, la necesidad de distinguir entre la naturaleza de las rentas y la de las utilidades operativas era fundamental para el análisis tanto de la distribución como del crecimiento. De hecho, para Ricardo (1959) el principal problema de la teoría económica era que Adam Smith y otros grandes pensadores, al no tratar correctamente el principio de la renta, pasaron por alto muchas verdades fundamentales, que solo pueden descubrirse después de que el tema de la renta se analice con la profundidad que requiere. Todo lo anterior también se relaciona con el fenómeno de la persistencia de las instituciones disfuncionales en el pasado reciente de América Latina, en particular, con la "ley de hierro de las oligarquías", según la cual instituciones que obstruyen el desarrollo tienden a reconstruirse (con Chile como estudio de caso).

En los Estados Unidos, por ejemplo, como describen Acemoglu y Robinson (2006), las élites terratenientes tradicionales pudieron mantener su control del sur durante un siglo después de perder la guerra civil, bloqueando con éxito las reformas económicas que podrían haber socavado su poder,

\footnotetext{
Agradezco a Alex Cobham y Andy Sumner por sus valiosas contribuciones a mi trabajo sobre la desigualdad. Muchos amigos y colegas, en particular Javier Núñez y la vieja guardia de estudiantes de doctorado de Cambridge han contribuido enormemente a mi trabajo sobre este tema. También lo han hecho (entre otros) Mariana Chudnovsky, Camila Cociña, Jorge Fiori, Juliano Fiori, Daniel Hahn, José Antonio Ocampo, Cristóbal Palma, Carlota Pérez, Ignês Sodré, Lance Taylor, José Valenzuela y Robert Wade. Carlos Díaz Alejandro fue un maestro. Este artículo está dedicado a Diego Armando Maradona, "el Pelusa", un símbolo de nuestra cultura latinoamericana, con todos sus triunfos y derrotas, con su fuerza vital como su poder de autodestrucción (el tema de este artículo no es una excepción). Se aplican los descargos habituales.

2 Véase Palma (2019b).
} 
y utilizando su supremacía política en el ámbito local para privar de sus derechos a los afroamericanos y volver a ejercer el control sobre la fuerza de trabajo. Asimismo, en América Latina las oligarquías disfuncionales han sido muy eficaces a la hora de reconstruirse después de sucesivas crisis políticas. Independientemente de lo que el resto de la sociedad les haya deparado, han sido capaces de rediseñar los nuevos escenarios en algo parecido a una configuración política (political settlement, en el sentido de Khan (2018)) y estructura distributiva tipo "Sur de los Estados Unidos" posguerra civil.

El análisis tomará como caso de estudio el cómo la élite chilena ha logrado transformar con éxito su escenario preferido "estilo sureño norteamericano" en algo que se aproxima a un "proceso estacionario", en el sentido de que impactos desequilibrantes (como, por ejemplo, el colapso económico de 1982 y el retorno a la democracia en 1990) solo han tenido efectos temporales. Si bien la historia de América Latina está plagada de crisis, sus oligarquías han podido rediseñar los nuevos escenarios de forma tal que han logrado seguir haciendo realidad sus perennes objetivos rentistas.

En el caso de América Latina lo han hecho principalmente a través de tres canales: en primer lugar, imponiendo camisas de fuerza al estilo buchaniano en los nuevos escenarios para limitar el alcance de la transformación social, como cuando impusieron en la joven democracia chilena una constitución draconiana y una serie de "leyes de amarre". En segundo lugar, han tenido la suficiente flexibilidad como para poder rediseñar sus estrategias distributivas adecuándolas a los nuevos escenarios, a la vez que han logrado mantener su "acción colectiva" (collective action). Finalmente, en tercer lugar, han absorbido hábilmente elementos de ideologías opuestas (como ahora la necesidad de tener una protección social efectiva), para así poder mantener su ideología como hegemónica en el nuevo escenario -según Gramsci (2000), cualquier ideología que aspire a conservar su hegemonía, tiene que ser capaz de hacer esto. Sus cartas de triunfo han sido el tener la fuerza como para imponer su voluntad en el primer canal, su flexibilidad (jogos de cintura e jeitinhos) y capacidad para mantener su "acción colectiva" en el segundo, y su maleabilidad ideológica en situaciones de apremio en el tercero.

Desde la perspectiva de la flexibilidad en sus estrategias distributivas (sus "juegos de cintura"), como demuestra la experiencia chilena, la élite capitalista latinoamericana ha sido capaz (hasta ahora) de seguir con éxito una estrategia distributiva compleja que podría vincularse con lo que en la teoría de los juegos se conoce como "paradoja de Parrondo", o una secuencia ganadora de estrategias en sí perdedoras ${ }^{3}$. En su formulación tradicional, esta paradoja consiste en dos juegos que tienen lugar alternativamente. Si se analiza cada juego de forma aislada se ve que ambos son juegos perdedores si se juegan indefinidamente (es decir, tienen una expectativa negativa). Sin embargo, cuando se juegan en forma alternada, el juego compuesto resultante es, paradójicamente, un juego ganador. En otras palabras, es posible -como en Chile- crear una estrategia ganadora con juegos distributivos aparentemente perdedores cuando se los juega en forma secuencial.

Queda por ver si en un futuro cercano la oligarquía chilena logrará hacer esto otra vez en el nuevo escenario creado por el estallido social de octubre de 2019 y la pandemia de COVID-19. Es decir, está por verse si esta vez consigue rediseñar con éxito su estrategia distributiva (por cuarta vez desde que logró derrocar al Gobierno de la Unidad Popular en 1973), ahora reconstruyendo su régimen de dominación con una nueva agenda social basada en su recién descubierto discurso estilo "nueva" socialdemocracia europea.

Cada una de las tres estrategias distributivas anteriores, por exitosas que hayan sido, tenía una vida útil limitada después de la cual se transformaban en contraproducentes; de continuar su implementación, se habrían convertido en estrategias perdedoras. El secreto del éxito distributivo de la oligarquía en el largo plazo ha sido precisamente su capacidad para cambiar su estrategia distributiva a tiempo (manteniendo su cohesión interna), mientras conserva su ideología como hegemónica.

3 Véase Parrondo (1996). 
De volver a hacerlo, se confirmaría cuán "estacionaria" es la naturaleza del actual régimen de dominación en cuanto a su capacidad de absorber cambios y sobresaltos sin alterar su estructura fundamental, es decir, logrando que el impacto de dichos cambios sea solo temporal. De lo contrario, significaría que el estallido social de octubre de 2019 pasaría a los anales de la historia chilena como el hecho que finalmente logró un efecto permanente en la estructura concentradora y excluyente del régimen oligárquico chileno. Es decir, sería el impacto que redefiniría la configuración política y estructura distributiva chilena en algo afín a un proceso tipo "raíz unitaria", en el cual la fuerza de un impacto no decaería con el tiempo. De esta forma, la oligarquía perdería su gran capacidad histórica de revertir el cambio a su favor.

Como mi análisis de la desigualdad proviene de la tradición ricardiana de entenderla como el resultado de la articulación política del conflicto distributivo -en que la historia, la política y las instituciones es lo que realmente importa-, mi análisis hace hincapié en Gramsci más que en Kuznets, en Hirschman más que en Solow, y en Mazzucato, Amsden o Pérez más que en interpretaciones tradicionales de la relación entre la tecnología y la desigualdad. El énfasis reside en la especificidad de procesos endógenos más que en las fuerzas fundamentales del universo.

Lo más importante para ello son cuestiones como qué es lo que contribuye a la formación de las creencias colectivas. ¿Cómo surgen los distintos tipos de consensos hegemónicos? ¿Cómo pueden cambiarse? ¿Por qué los conflictos "antagónicos" se asocian con la formación de fuertes identidades políticas, en las que se invierte tanta energía libidinal? Es decir, mi forma de entender la desigualdad se relaciona más con la ideología que con la tecnología; con la capacidad de agencia más que con la estructura (siempre que aquellas sean capaces de comprender la estructura); con la articulación discursiva más que con el determinismo económico; y con la voluntad más que con accidentes históricos (de los que habla Piketty ${ }^{4}$ ). En definitiva, con el combatir (con determinación keynesiana) las "fallas distributivos" creadas artificialmente en la esfera de la producción, en lugar de rendirse a la desigualdad mercado al estilo de la "nueva" izquierda en Europa y América Latina. Como se analiza en el anexo A2 (y en detalle en Palma, 2019a), si bien en Europa los Gobiernos hacen esfuerzos titánicos de redistribución mediante impuestos, transferencias y deuda pública, parecen tener pocos problemas para dejar que grandes agentes distorsionen los mercados a su favor, creando en forma artificial la necesidad de dicho gasto faraónico en protección social (equivalente a aproximadamente a un cuarto del PIB si se incluyen todos sus elementos).

Todas estas complejidades hacen que el análisis de la desigualdad sea particularmente difícil, puesto que se trata de un fenómeno complejo y de seguro, sobredeterminado, lo que significa que nuestra modesta comprensión de su dinámica en el mundo real (a pesar del progreso reciente) sea una de las flaquezas analíticas más importantes del análisis económico actual ${ }^{5}$.

De hecho, Krugman (2011) identificó la creciente desigualdad en los países desarrollados y el eterno desempeño económico insuficiente de América Latina como los dos desafíos analíticos más importantes actualmente en economía. Sin embargo, desde mi punto de vista, el desafío analítico real es entender la interacción entre los dos fenómenos, tanto en las economías maduras como en las economías emergentes, dado que las economías de altos ingresos de la Organización para la Cooperación y el Desarrollo Económicos (OCDE) ahora están empeñadas en replicar tanto la desigualdad implacable como el eterno desempeño insuficiente de América Latina. Como decíamos, el análisis de Ricardo facilita esta tarea.

4 En su primer y muy influyente libro, para Piketty no existe una tendencia natural a la disminución de la desigualdad ni siquiera cuando un país alcanza la madurez económica. En su modelo neoclásico (por necesidad, mecanicista), se supone que la creciente desigualdad es inherente a una economía capitalista con independencia de su configuración política y nivel de desarrollo (Piketty, 2014). En su opinión, se necesitaron accidentes como las dos guerras mundiales y una gran depresión para perturbar este supuesto patrón (véase un análisis de este tema en Palma (2019a, apéndice 2). Sin embargo, en su siguiente contribución (Piketty, 2020) finalmente quita importancia al papel de factores exógenos como los accidentes históricos y acentúa el de la ideología.

5 Para algunas contribuciones recientes, véanse Atkinson (2015); Bourguignon (2017); Galbraith (2016); Milanovic (2016 y 2019); Ocampo (2019); Palma (2011, 2016a y 2019a); Piketty (2014 y 2020); Scheidel (2017) y Taylor (2020). 
Este proceso de "latinoamericanización" de la OCDE, que ya analicé en Palma (2011 y 2016b), y luego en Palma (2019a), se asemeja a un proceso de "cerrar brechas al revés" (reversed catching-up) de las economías de altos ingresos con las del trópico. La naturaleza de las actividades económicas pudo haber cambiado desde Ricardo, pero el bajo rendimiento económico (en especial el de la productividad) resultado de un incremento de la desigualdad liderado por las rentas no productivas (incluidas las de ineficiencia) y en contra de las utilidades operativas no lo ha hecho. Y no hay que olvidar que en el modelo de crecimiento de Ricardo el "equilibrio de largo plazo" (steady state) es uno en el cual los salarios se estancan, los capitalistas no obtienen ganancias operativas y las rentas se llevan la tajada del león. El paradigma tecnológico, los mercados financieros y las instituciones habrán cambiado, pero el "equilibrio de largo plazo" que se visualiza en América Latina y la OCDE en torno a esta trilogía es igualmente tóxico tanto para la desigualdad como para el crecimiento y la democracia.

Sin embargo, la especificidad de las configuraciones políticas y las estructuras distributivas de América Latina no se relaciona solamente con desigualdades autoconstruidas artificialmente que ahogan el crecimiento, sino también con la forma en que las élites capitalistas de la región (dejemos la cuestión de si realmente son capitalistas para más adelante) han demostrado una notable "capacidad de persistir" frente a todo tipo de crisis, incluso cuando ellas tienen relación directa con sus formas rentistas e ineficientes de acumulación.

Hasta ahora la pandemia ha aportado un ejemplo más de este fenómeno: si bien la actividad económica y el nivel de vida de tantos han quedado diezmados, la mayoría de las grandes fortunas (especialmente las financieras) han seguido expandiéndose como en los mejores momentos (Palma, 2020a).

Además, con la pandemia, esta asimetría entre la capacidad de la oligarquía de permanecer siempre a flote, pase lo que pase, cueste lo que cueste, y la vulnerabilidad del resto de la sociedad ha echado a retroceder mucho de lo que se había conseguido en estos últimos años en América Latina en cuanto a la reducción de la pobreza y las pequeñas mejoras en la desigualdad.

El problema fundamental de la economía política en América Latina es que no hay muchas maneras de remodelar la estructura de un sistema con tan poca entropía. Es difícil rediseñar la estructura de nuestra sociedad y economía de modo que pueda avanzar en el tiempo si los fundamentos de su statu quo tienen que permanecer invariables, de modo que los de arriba puedan continuar apropiándose de una parte ingente del ingreso nacional -y por hacer el tipo actividades que hace-. El principal problema con un sistema de este tipo es que tiene que dedicar tanta energía a intentar "detener" el tiempo que queda poca para moverse hacia adelante.

Una hipótesis analítica clave planteada aquí es que la experiencia de América Latina demuestra que en lugar de pensar (en términos neoclásicos) en los posibles efectos concretos que algunos factores bien conocidos (como la tecnología o la educación) pueden tener en la desigualdad, sería más esclarecedor intentar comprender las expresiones concretas que estos factores tienen en la desigualdad. Algunas de las piezas del rompecabezas distributivo pueden ser las mismas en distintas experiencias de desigualdad, pero la forma en que encajan puede variar (a veces, significativamente).

Es decir, la especificidad de la desigualdad en América Latina proviene de las formas particulares en que se han manifestado sus luchas distributivas, las distintas estrategias que han adoptado las oligarquías para hacer frente a dichas luchas y superarlas temporalmente (el tema principal de este artículo) y los nuevos desafíos distributivos creados por este proceso.

Algunos continúan atribuyendo la desigualdad de América Latina a las instituciones coloniales de hace 500 años, como el sistema de la "mita" (servicio público obligatorio de la población indígena) y la "encomienda" (que recompensaba a los conquistadores con el trabajo de algunos grupos específicos de los pueblos conquistado) 6 . Otros, como en muchas narrativas neoclásicas, la analizan de una

6 Para Williamson (2009) - y con razón - la supuesta persistencia monótona de la desigualdad en América Latina es solo un mito. 
manera que se asemejan a la física newtoniana; es decir, con metodologías del determinismo mecánico y las causalidades simples (estilo física del siglo XIX, pero con signo " $\$$ ") ${ }^{7}$. Hay quienes llegan a culpar a la falta de grandes guerras, ya que supuestamente en los países de la OCDE y en algunas de las economías asiáticas emergentes de la primera oleada de industrialización solo fue posible mejorar la distribución del ingreso después de grandes conflictos (Scheidel, 2017; Piketty, 2014).

La monótona insistencia de muchos en atribuir la enorme desigualdad en América Latina a factores exógenos o a la simple trayectoria histórica (path dependency) es como usar un par de tijeras para cortar un nudo analítico que no consiguen deshacer.

A su vez, es desafortunado que Piketty (2014), en su primer libro y el más influyente, al basarse innecesariamente en la teoría neoclásica del crecimiento (el de la participación de los factores), llevara en la dirección analítica equivocada el debate sobre el aumento de la desigualdad en la mayoría de los países de la OCDE, desde Reagan y Thatcher. Básicamente, en su teoría neoclásica, de haber demasiado de algo bueno -en su análisis, dos cosas buenas: mucha inversión y alta elasticidad de sustitución entre factores (flexibilidades productivas)- terminará por haber, lamentablemente, una mayor desigualdad. ¡Sería difícil imaginar un esquema que pudiese idealizar aún más la desigualdad!? .

En cambio, como hemos argumentado Stiglitz (2012) y yo (Palma 2011, 2016a y 2019a), la desigualdad es una opción entre alternativas perfectamente factibles en un mundo de equilibrios múltiples. Como argumentó Sartre (2004), nada revela de forma más clara quiénes somos en realidad que las decisiones que elegimos tomar; esto ciertamente es el caso de la desigualdad. La conclusión, como indica el título de Palma (2016a), es que cada país se merece la desigualdad que tiene.

Sencillamente ya no es creíble seguir afirmando que en cuanto a la desigualdad somos espectadores inocentes, a merced de factores "externos"9. Hay que rechazar los determinismos mecánicos y las causalidades simples e insistir en nuestra libertad y responsabilidad últimas. "Yo soy mi libertad", dice un personaje de una de las obras de Sartre (Sartre, 1946). Cada acto se define a sí mismo y ningún acto de esta naturaleza puede atribuirse a los así llamados factores exógenos. La cita clásica por antonomasia sobre este tema nos la da Shakespeare en un discurso de El Rey Lear:

"¡He aquí la excelente estupidez del mundo; que, cuando nos hallamos a mal con la Fortuna, lo cual acontece con frecuencia por nuestra propia falta, hacemos culpables de nuestras desgracias al sol, a la luna y a las estrellas; como si fuésemos villanos por necesidad, locos por compulsión celeste; pícaros, ladrones y traidores por la fuerza de los astros; beodos, embusteros y adúlteros por la obediencia forzosa al influjo planetario, y como si siempre que somos malvados fuese por empeño de la voluntad divina. ¡Admirable subterfugio del hombre libertino, cargar a cuenta de un astro su deshonesta condición!" (Shakespeare, s. f.)

\footnotetext{
7 No debería sorprender, entonces, que la mayoría de los análisis neoclásicos de la desigualdad en América Latina no logren explicar por qué es mucho mayor allí que en muchos países de ingresos medios en lugares como Asia, el Norte de África, la antigua Unión Soviética y Europa Oriental (entre otros), aunque algunas de las cuestiones que destacan parecen apuntar en la dirección opuesta. Por ejemplo, prácticamente todos los países anteriores suelen tener incluso más rigideces y fallas de mercado que América Latina; tienen una estructura relativa de precios, unas instituciones y un capital social que son aún menos "correctos"; tienen derechos de propiedad sobre los activos físicos e intelectuales que están menos demarcados y se hacen cumplir en menor medida; tienen unos sistemas educativos que están aún más segmentados, y los pobres suelen salir incluso más malparados; discriminan por razón de género y de raza incluso más que en América Latina; tienen una escasez aún mayor de mano de obra cualificada; sus democracias son incluso de más "baja intensidad" y con más problemas de "gobernanza", y dependen aún más de los contactos políticos, el amiguismo (cronysm) y la corrupción para lograr el éxito en los negocios. Pero, a pesar de todo esto, esos países son menos desiguales que América Latina (a veces de manera significativa).

8 Para leer una crítica del análisis neoclásico de Piketty, véanse Rowthorn (2014); Taylor (2014 y 2020); Harcourt (2015), y Palma (2019a, especialmente el apéndice 2).

9 Kaldor (1955) fue el primero en conjurar el hechizo mecanicista neoclásico de los determinantes de la desigualdad en su análisis del modelo Harrod-Domar, que provocó una fuerte reacción de Solow (1956). Mientras Kaldor abordaba el problema de la inestabilidad en el modelo de Harrod-Domar introduciendo cambios endógenos en la distribución del ingreso entre salarios y rentabilidad del capital, Solow argumentaba que era absurdo pensar en una distribución eficiente de los ingresos que no estuviera automática (y mecánicamente) determinada por el valor de las productividades marginales.
} 
Al menos parece que finalmente se está convirtiendo en "sentido común" (en la perspectiva de Gramsci) el hecho de que la creciente distribución mercado que ha caracterizado el panorama mundial desde Reagan y Thatcher ha sido una falla distributiva autoconstruida. Warren Buffett lo explica de manera clara y sucinta: "Claro que hay lucha de clases, pero es mi clase, la clase de los ricos, la que está impulsando esta guerra. ¡Y la estamos ganando!" (Véase Stein, 2006). En cuanto a la creciente desigualdad, ¿los fundamentos? ¡Qué fundamentos!

Básicamente, si existiera la "mano invisible" de Adam Smith (Smith, 1776) y fuera lo que guiara la asignación de recursos, este implacable aumento de la desigualdad, sobre todo la desigualdad mercado (véase el anexo A2), no podría haber tenido lugar, porque las compulsiones del mercado no la hubiesen permitido. Sus cimientos fueron hechos artificialmente a medida. De hecho, ya es casi aburrido tener que repetir que la creciente desigualdad mercado es una falla distributiva artificial, una simple distorsión de mercado; es como si alguien en el circo, cuando el mago corta a una mujer por la mitad, dijera: "ies solo un truco!".

\section{Algunos antecedentes}

\section{Efectos de trinquete (ratchet effect) o la inflexibilidad a la baja de los incrementos de la desigualdad}

Uno de los temas que analizaré en este artículo (hasta ahora bastante desatendido en la literatura), que ha demostrado ser un hecho distributivo estilizado importante en la América Latina de posguerra, es el efecto de trinquete (ratchet effect): las mejoras en la desigualdad han tendido a ser temporales, mientras que los deterioros tienen efectos más permanentes. Es decir, las conocidas dificultades para revertir la dinámica social parece que solo hacen referencia a los aumentos de la desigualdad. Los acontecimientos en Chile lo ilustran claramente: el salto en la parte superior de la escala de ingresos ha sido difícil de revertir (véase el gráfico 1).

Lo más llamativo es que ese trinquete en la parte superior se produjo a pesar de que Pinochet perdió el plebiscito por un amplio margen, y que en el período posterior al retorno a la democracia hubo cuatro gobiernos consecutivos de centro-izquierda, todos dentro de una coalición política que incluía el Partido Socialista del Presidente Allende. Además, esta coalición política contó con el apoyo de una clara mayoría en las elecciones presidenciales y las parlamentarias en todo momento, y uno de los lemas en su discurso y manifiestos fue reducir la desigualdad. Los apartados III a VII desarrollan una narrativa que intenta explicar por qué fracasaron en este objetivo (al menos en términos de poder reducir la participación en los ingresos de los ricos). 


\section{Gráfico 1}

Chile: participación del 1\% más rico en el ingreso mercado (antes de impuestos), el legado distributivo de la dictadura, 1964-2015

(En porcentajes)

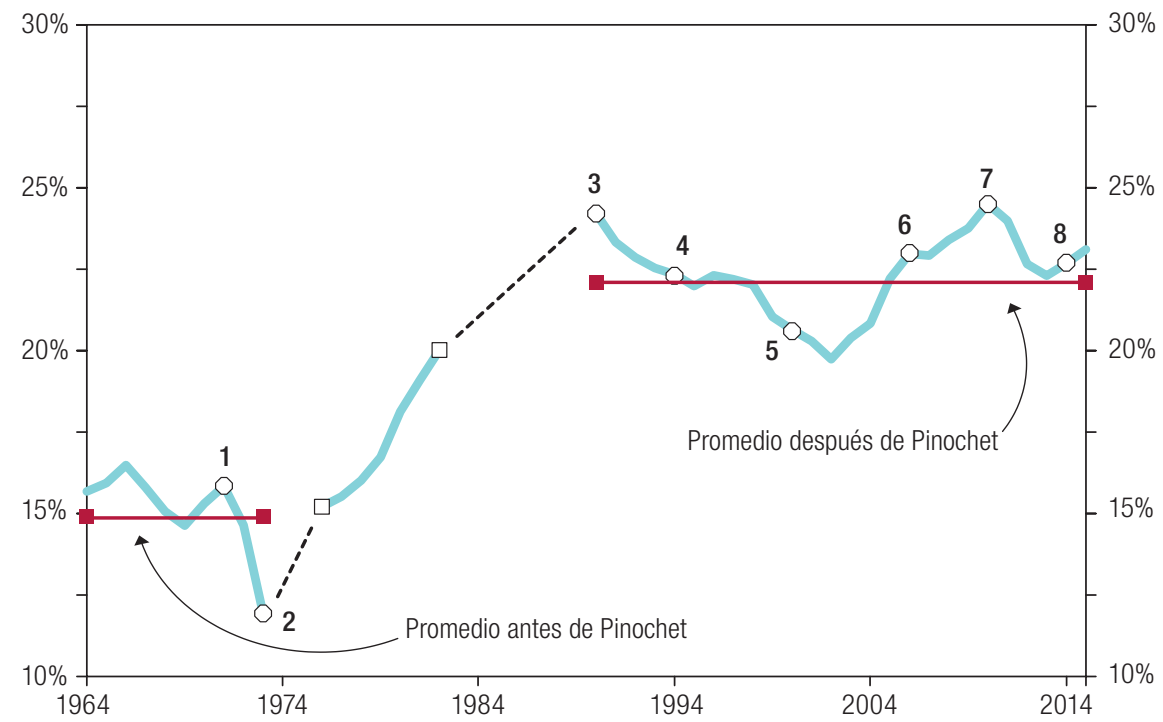

Fuente: World Inequality Lab, World Inequality Database, 2020 [en línea] http://wid.world/, sobre la base de J. Atria y otros, "Top incomes in Chile: a historical perspective of income inequality (1964 -2015)", Working Paper Series, № 2018/11, World Inequality Lab, 2018.

Nota: Las líneas punteadas se refieren a los años para los cuales no hay datos disponibles. Durante el período 1964-1981 los ingresos se refieren a "ingresos fiscales", y a partir de 1990 a "ingresos nacionales antes de impuestos". Los promedios son medias armónicas ${ }^{10}$ (1957-1973 y 1990-2015). Promedios móviles trienales.

1. Elección de Salvador Allende.

2. Pinochet toma el poder en un golpe de Estado.

3. Pinochet se ve obligado a convocar un plebiscito sobre si puede permanecer en el poder otros ocho años, lo que da lugar al primer gobierno democrático (una coalición de centro-izquierda, la "Concertación") después de que Pinochet pierde el plebiscito.

4,5 y 6 . Los siguientes tres gobiernos de centro-izquierda.

7. Elección de un gobierno de derecha.

8. La centro-izquierda regresa al gobierno.

Entre otros trinquetes distributivos regionales destaca el caso del Brasil. La oligarquía brasileña no solo pudo mantener el aumento de la desigualdad que siguió al golpe de Estado de 1964, sino que, además, continuó disfrutando de estos beneficios mucho después del retorno a la democracia; de hecho, al menos hasta la elección de Luiz Inácio Lula da Silva (véase el gráfico 2) ${ }^{11}$. Esta notable persistencia de una gran desigualdad (como mucho con pequeñas mejoras) también se da en otros países de la región.

\footnotetext{
10 Para los no especialistas, la media armónica es una de las tres medias pitagóricas. Es más apropiada para el promedio de las ratios ya que mitiga el impacto de los valores extremos; también contiene más información que la mediana. Es la recíproca de la media aritmética de las recíprocas.
}

11 Véase más información sobre el rápido deterioro de la desigualdad después del golpe de Estado de 1964 en Fishlow (1972). 


\section{Gráfico 2}

Brasil, México, Costa Rica y Colombia: índices de Gini del ingreso mercado y del ingreso disponible, entre 1960 y 2018
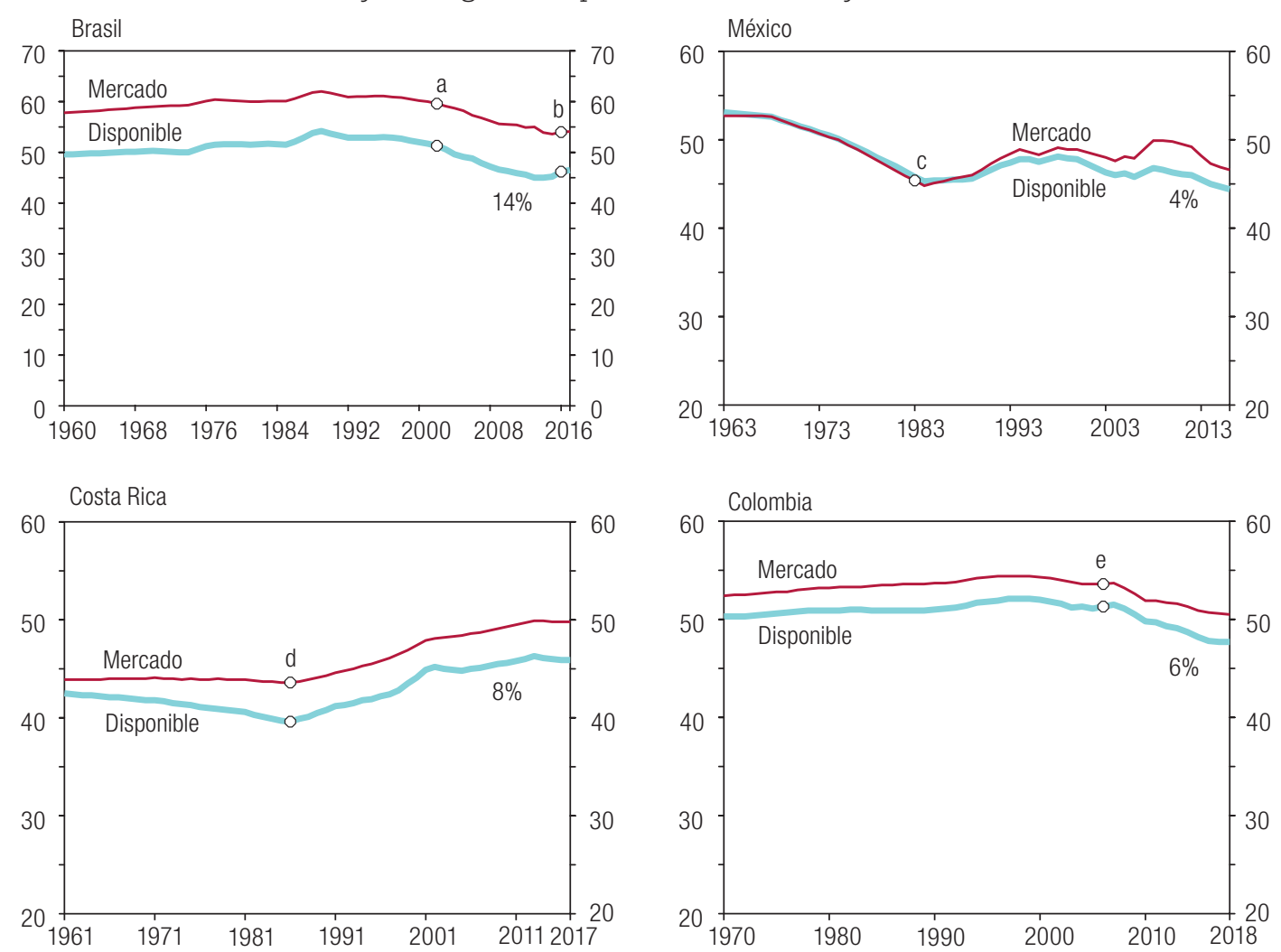

Fuente: F. Solt, "Measuring income inequality across countries and over time: the Standardized World Income Inequality Database", Social Science Quarterly, vol. 101, № 3, SWIID version 9.0, octubre de 2020 [en línea] https://fsolt.org/swiid/.

Nota: Los porcentajes mostrados en los paneles indican la reducción relativa del índice de Gini de ingreso mercado después de impuestos y transferencias.

a. Elección de Luiz Inácio Lula da Silva.

b. Golpe de Estado parlamentario contra Dilma Rousseff.

c. Elección de Miguel de la Madrid.

d. Elección de Óscar Arias.

e. Reelección de Álvaro Uribe.

Como indica el gráfico 2, los países de la región difícilmente alcanzan los dos dígitos cuando se trata de reducir su desigualdad mercado a través de los impuestos y las transferencias. Estos esfuerzos son mínimos en comparación con los de los países europeos, que mejoran el índice de Gini hasta en un 50\% (véase el anexo A2). Son exiguos incluso en comparación con los de los Estados Unidos durante la administración del Presidente Trump (25\%). ¿Por qué América Latina ha logrado tan poco a pesar de tanto discurso "progresista"?

Además, si bien Brasil es el país que reduce más el Gini mercado (14\%) en la región -cifra similar en Sudáfrica- es un esfuerzo especialmente modesto si se toma en cuenta que en ambos países los ingresos fiscales son relativamente similares al promedio de la OCDE (Di John, 2006; Lieberman, 2003; OCDE, 2020a). La gran diferencia entre ellos es que Sudáfrica, a pesar de su tributación relativamente progresiva, no consigue hacer más debido a un sistema ineficaz de transferencias a los pobres, mientras que el Brasil, aunque tiene (¿o debo ahora decir tenía?) un sistema más eficaz de transferencias, también tiene un punto débil: su estructura de tributación muy regresiva.

De hecho, otra fuente (World Inequality Lab, 2020) incluso cuestiona la mejora relativamente pequeña del Brasil en materia de desigualdad de ingresos disponibles según surge de las encuestas de 
hogares durante los cuatro gobiernos sucesivos del Partido de los Trabajadores (PT). Es muy probable que el trinquete brasileño que favorece a los grupos de altos ingresos, al igual que el chileno, haya permanecido incluso durante el período de gobiernos de centro-izquierda (véase el gráfico 3).

\section{Gráfico 3}

Brasil: participación del 1\% más rico y el 10\% más rico en el ingreso nacional antes de impuestos y el índice de Palma sobre la desigualdad en ingresos disponibles (después de impuestos y transferencias), 2001-2019

(En porcentajes)

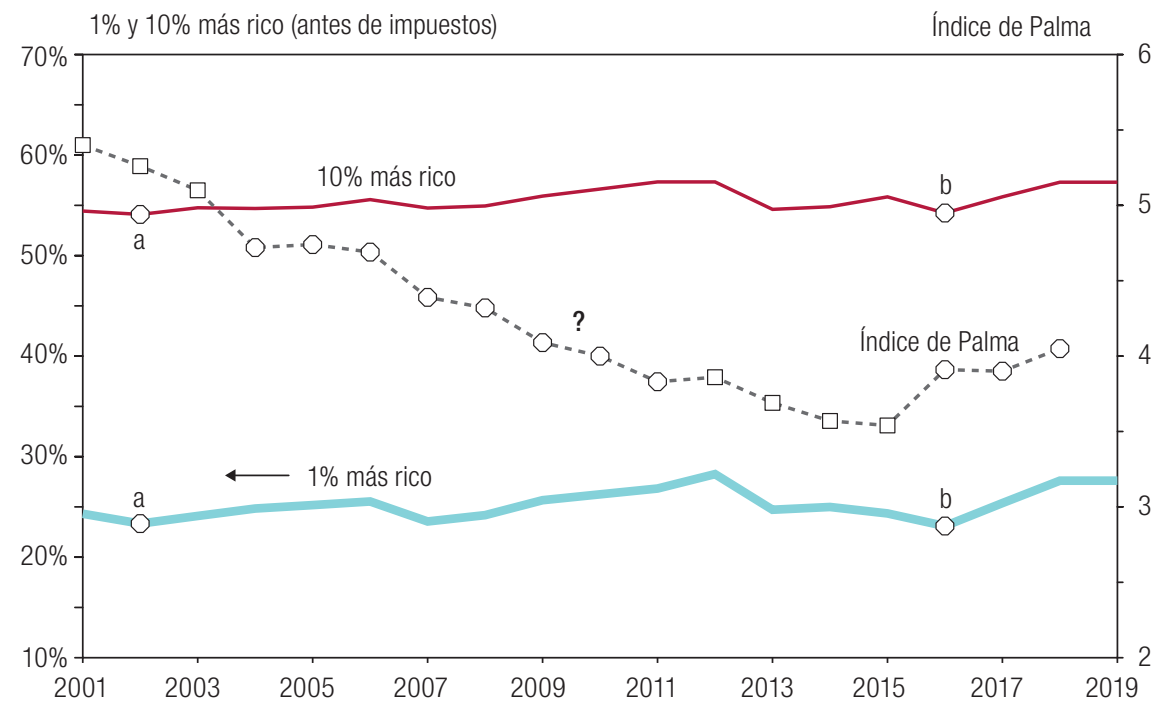

Fuente: World Inequality Lab, World Inequality Database, 2020 [en línea] http://wid.world/, sobre la base de M. De Rosa, I. Flores y M. Morgan, "Inequality in Latin America revisited: insights from distributional national accounts", Technical Note, № 2020/02, 2020 (para el ingreso antes de impuestos); y J. G. Palma, "Behind the seven veils of inequality: what if it's all about the struggle within just one half of the population over just one half of the national income?", Development and Change, vol. 50, № 5, septiembre de 2019 (para el coeficiente de Palma).

Nota: a. Elección del presidente Luiz Inácio Lula da Silva.

b. Golpe de Estado parlamentario contra la presidenta Dilma Rousseff.

Hay pocos indicios de que la pequeña disminución que supuestamente tuvo lugar en la participación en los ingresos disponibles de los más ricos durante la era del PT, de acuerdo a encuestas de presupuesto familiar, sea realidad, dada la nueva evidencia preimpuesto y la regresividad tributaria del Brasil. Como en el caso chileno en el gráfico 9, lo más probable es ello no se deba a otra cosa que la creciente incapacidad de las encuestas de presupuesto para reflejar los ingresos de los ricos en este mundo cada vez más financierizado (y lleno de paraísos fiscales). Incluso las políticas (exitosas) del período del PT para mejorar la participación de los más pobres (como la reducción de la pobreza, la formalización de contratos laborales y el aumento del salario mínimo) no serían suficientes como para justificar la supuesta mejora del índice de Palma (ver signo de interrogación en el gráfico 3).

Además, estas políticas, así como las políticas para frenar la destrucción de la Amazonia, ahora peligran no solo por el impacto económico de la pandemia, sino también por la política actual del Gobierno con respecto a la pandemia de COVID-19, el nacionalismo descaminado en la Amazonia y el tipo de neoliberalismo-Chicago presente en las políticas económicas ${ }^{12}$.

\footnotetext{
12 A la luz de la pandemia actual, si continuamos destruyendo hábitats y ecosistemas, se van a hacer más probables los saltos de virus de animales a personas; en especial, la destrucción continuada de la Amazonia podría llevar a la próxima crisis sanitaria. En el momento de redactar este artículo, incluso zonas fuera de la Amazonia, como el Pantanal, están siendo arrasadas por el fuego; de hecho, más de una cuarta parte de su humedal tropical ya ha sido destruido. Como habría dicho Einstein: "Dos cosas son infinitas: el universo y la estupidez humana" (para luego agregar que no estaba seguro sobre el universo).
} 
Las tan celebradas pequeñas mejoras en la desigualdad de Chile exigen el mismo escepticismo (véanse los gráficos 1 y 9). Para aquellos en América Latina que quieren mejorar la desigualdad ha sido mucho más fácil hablar que actuar.

\section{Por qué las instituciones disfuncionales son tan efectivas para recrearse luego de impactos desestabilizadores}

Como se sugirió anteriormente, todo esto nos lleva de vuelta al complejo tema de la persistencia en las instituciones disfuncionales, y en particular a cómo son tan eficaces a la hora de reconstruirse a sí mismas, como lo hizo la élite terrateniente en el sur de los Estados Unidos después de perder la Guerra Civil. La oligarquía chilena también consiguió hacerlo, a pesar de perder claramente el plebiscito de 1988 y cuatro elecciones presidenciales y parlamentarias después. Como los tiempos han cambiado, a la oligarquía le ha resultado más eficaz coaptar el objeto de su odio que lincharlo. Sin embargo, los tiempos no han cambiado tanto: la oligarquía logró imponer a la mayoría una camisa de fuerza con forma de constitución, con muchas instituciones que escapan al control democrático. A su vez, gracias a las supramayorías necesarias en el Parlamento para cualquier cosa significativa y los senadores "designados" (incluido el propio Pinochet), esas instituciones por encima del control democrático volvieron prácticamente imposible modificar la Constitución. Fue necesario un estallido social de la magnitud del de octubre de 2019 para desestabilizar el "equilibrio tipo Sur de Estados Unidos" en Chile lo suficiente como para obligar a los líderes empresariales a convencer a los poderes existentes de que iniciaran un cambio constitucional. Cuando se celebró el referéndum sobre esta posibilidad, exactamente un año después del estallido social (y 30 años después del retorno a la democracia), obtuvo una respuesta favorable del $80 \%$ de los votantes.

En cuanto al papel que desempeña la "nueva" izquierda en todo esto (véase el anexo A1), según Gramsci (2000), cualquier ideología que pretenda seguir siendo hegemónica debe ser capaz de absorber elementos de las ideologías opuestas, pero tiene que hacerlo de forma imaginativa, articulándolas en la esencia de su propia ideología. Es decir, para que un consenso siga siendo hegemónico, los grupos dominantes deben hacer concesiones ideológicas ante los grupos subordinados, pero sin poner en peligro su dominio. Esto fue lo que hicieron tan bien el empresariado y los partidos políticos de derecha en Chile después de su derrota en el plebiscito de 1988, y lo que les ayudó controlar la transición hacia la democracia, donde las autoridades elegidas de centro-izquierda pudieron dirigir el gobierno, pero la élite empresarial retuvo el poder político de facto, mientras que los militares (con Pinochet como Jefe de las Fuerzas Armadas durante ocho años más) retuvo el de la fuerza.

Mientras tanto, los partidos de centro-izquierda, inspirados por la "tercera vía" de la nueva socialdemocracia de Europa Occidental, hicieron ese esfuerzo de imaginación ideológico e integrador de Gramsci de una manera tímida, a menudo oportunista, y con poca creatividad. Como resultado, permitieron que la nueva ideología económica neoliberal simplemente sustituyera su ideología socialdemócrata.

Aquí las semejanzas con lo que sucedió en Sudáfrica después del inicio de la democracia en 1994 también son más que superficiales: quizás la élite política de los afrikáneres perdió la más grande de las batallas, pero la élite blanca (en parte gracias a haber captado una masa crítica de la élite del Congreso Nacional Africano (ANC)) se sigue apropiando más del ingreso nacional que cualquier otra élite en el mundo (Palma, 2011, apéndice 3).

Desde esta perspectiva, como señalan Acemoglu y Robinson (2006), nunca se debe perder de vista la distinción entre los dos componentes del poder político, el poder de jure y el poder de facto. La desgracia política de América Latina es que el poder político de facto de la oligarquía es tal 
que estas instituciones disfuncionales han podido sobrevivir hasta ahora todo tipo de crisis políticas y económicas y salir bastante ilesas. La captura de la "nueva" izquierda latinoamericana ha resultado ser solo un capítulo en esa historia (véase el anexo A1).

\section{La desigualdad como un juego de anticoordinación, como en el juego "del gallina" (o "halcón-paloma")}

En la teoría de los juegos, este tipo de juego es un modelo de conflicto vinculado con una amplia gama de conflictos sociales. La cuestión es qué jugador cede primero, como en la película de 1955 Rebelde sin causa: los conductores corren una carrera hacia un precipicio en coches robados y quien salte primero del auto será considerado "el gallina". Bertrand Russell (1959) también lo utilizó, como es bien sabido, como una metáfora del juego de la política nuclear dispuesta a llegar al "borde del abismo" -donde el resultado final podría ser uno que nadie quería-.

Se trata de un juego de "anticoordinación" porque el recurso compartido es un bien "rival" (aunque no excluyente). A saber, compartir tiene un costo, es decir, está sujeto a una externalidad negativa. Este, por supuesto, no tiene por qué ser el caso en los juegos distributivos si los jugadores se encuentran en un escenario de salarios de eficiencia al estilo de Marshall, debido a la probable retroalimentación positiva entre el crecimiento de los salarios y el crecimiento de la productividad. Sin embargo, intente explicárselo a una oligarquía miope convencida de que sus ingresos dependen de no entender.

La inestabilidad que caracteriza el juego del gallina da lugar a una situación en la que solo hay dos equilibrios de Nash posibles (y opuestos), correspondientes a la estrategia preferida de cada jugador ${ }^{13}$. Cualquier cosa intermedia es un resultado mixto inestable, siempre abierto a ser desafiado. Uno que resulta de la articulación temporal y precaria de prácticas contingentes, es decir, como en otros conflictos antagónicos, este sería producto de prácticas que buscan estabilidad en un contexto de contingencia. Así que una táctica efectiva (y particularmente relevante aquí) sería que una de las partes indicara sus intenciones de manera suficientemente convincente. En otras palabras, el juego podría convertirse fácilmente en un juego de extremos, como forma de evitar que el oponente pase a tener un comportamiento agresivo. Esta es una de las razones por las que en un conflicto distributivo antagónico un jugador "irracional" puede fácilmente llevar la ventaja. Y como las amenazas creíbles - por irracionales que sean - pueden ser muy eficaces, en temas de desigualdad el conjunto de las instituciones y las reglas donde se desarrolla el conflicto distributivo se vuelve crucial, ya que puede ayudar a la credibilidad de una u otra parte.

De hecho, una forma de entender las transformaciones neoliberales es en términos de la construcción de un escenario institucional específico en el cual los trabajadores y el Estado deben tomar muy en serio las amenazas de la élite (por irracional que sea). A estas alturas puede quedar poca duda que estas reformas tuvieron poco que ver (tanto en las economías maduras como en las emergentes) con una mayor eficiencia económica, y mucho que ver con ayudar al capital a recuperar el poder y la legitimidad perdidas con la crisis de los treinta, la determinación del presidente Franklin D. Roosevelt y su Nuevo Pacto (New Deal), el horror de la guerra, la creciente organización de la clase trabajadora y el genio de Keynes. Después de la guerra, incluso en los Estados Unidos los ingresos del $40 \%$ más pobre de la población crecieron más rápido que los del 1\% más rico por tres décadas consecutivas (Palma, 2019a).

\footnotetext{
${ }^{13}$ En este juego, el espacio estratégico para ambos jugadores sería exigir la redistribución y no exigir la redistribución para el jugador de la mayoría, y ceder a la redistribución y no ceder a la redistribución para la élite capitalista. Se trata de una historia de equilibrios múltiples. A su vez, los equilibrios de Nash serían "exigir la redistribución", "ceder a la redistribución" y "no exigir la redistribución", "no ceder a la redistribución" para el jugador de la mayoría y el jugador de la élite, respectivamente. En el primero, el jugador de la mayoría tiene la ventaja, mientras que en el segundo la tiene la élite.
} 
Uno de los objetivos de las reformas de los años ochenta era revertir esta situación. Desde la perspectiva de Walter Benjamin (1968), toda sociedad de clases se encuentra en un estado de emergencia permanente porque el grupo dominante siempre está bajo amenaza. El objetivo del neoliberalismo, pues, fue crear un consenso y una praxis -y un "sentido común"- que contribuiría a crear una sociedad de clases en la que la élite no estaría expuesta a esta amenaza por su capacidad de debilitar al resto de la sociedad imponiéndole una vida permanentemente insegura ${ }^{14}$. En este escenario, un agente móvil y maleable podría lograr un dominio inigualable. ¡En la selva, el gran capital (especialmente el financiero) es rey! Y en este contexto, cualquier estrategia alternativa de desarrollo y autonomía nacional conlleva el riesgo de convertirse en un pacto suicida colectivo.

Esto nos recuerda la propuesta de Foucault (2009) de que el neoliberalismo no es realmente un conjunto de políticas económicas sino una nueva y muy eficaz tecnología de poder (Frangie, 2008; Palma, 2016b). Así, los trabajadores vuelven a tener trabajos precarios a la antigua usanza; las redes de seguridad social se están haciendo deliberadamente cada vez más porosas; y el fácil acceso a la deuda persecutoria está llevando a lo que Krugman (2005) denomina "el regreso a una sociedad del peonazgo atado a deudas". A su vez, los "Estados subsidiarios" limitan sobremanera el rango de maniobra para la política económica o para sus agencias que no sean las destinados a complacer el gran capital.

Las incertidumbres de un nuevo paradigma tecnológico tampoco ayudan, ya que si bien abren oportunidades al capital financiero y a algunas habilidades e innovaciones específicas, introducen al mismo tiempo aún más incertidumbres para la mayoría de los trabajadores y el Estado (Pérez, 2002).

Lo esencial para el neoliberalismo es cómo reconstruir un escenario en el que no quepan dudas que el capital va a patear el tablero en cuanto haya algo que no le guste. En tales circunstancias, la aceptación ideológica de la estrategia (de juego) "preferida" de la élite podría considerarse sabia, en lugar de gallina, lo que haría que una posición tan desfavorable fuera más llevadera. El dolor compartido hasta puede resultar reconfortante. Al fin y al cabo, como también nos recuerda Benjamin (1968), antes de cualquier filosofía está la lucha por la subsistencia.

En los países en desarrollo el desafío para el capital de desarrollar formas más efectivas de legitimidad, y tecnologías más sofisticadas de apropiación del valor creador por otros, es incluso mayor. Con las nuevas complejidades del escenario posterior a la Guerra Fría, la existencia de un dictador o dos, como el del régimen militar de Chile, ya no es suficiente.

Si bien el discurso neoliberal llegó al escenario mundial en medio de la sed de nuevas ideas en la década de los setenta, prometiendo el orden, la eficiencia del mercado, la iniciativa individual, el no paternalismo, una macroeconomía sólida y un nuevo concepto de Estado, lo que realmente ofrecía a los trabajadores y al Estado era una vida al borde del abismo y un orden inestable y de alto riesgo en el que solo el capital, con su movilidad y maleabilidad, puede realmente prosperar, y donde el Estado queda básicamente reducido a apagar incendios, en una situación llena de emergencias.

En cierto modo las ideas de Keynes se referían precisamente a luchar contra estos tipos de "juegos de anticoordinación", ineficientes y anticuados, en busca de escenarios cooperativos, más eficientes y estables. El paradigma tecnológico de la producción en masa para el consumo en masa también facilitó este tipo de escenario, especialmente por estar en su etapa de madurez (Mazzucato, 2013 y 2018; Pérez, 2002). Por su parte, si el capital o los trabajadores forzasen las cosas hacia situaciones abiertamente conflictivas, lo imperativo para Keynes era evitar que un jugador propenso a comportamientos irracionales - como el capital financiero - logre intimidar a los demás en un juego del tipo gallina.

\footnotetext{
14 Véase Arantes (2007).
} 


\section{La capacidad de persistir de la élite capitalista chilena}

Como ya se sugirió, una posible explicación de la obstinadamente estable alta desigualdad de Chile es que se ha beneficiado de la paradoja de Parrondo en el sentido de que la oligarquía chilena parece haber seguido con éxito una estrategia distributiva compleja afín a esa lógica. En la teoría de los juegos, el secreto de esta paradoja es cambiar de estrategia cuando el juego se transformase en contraproducente (cuando ha pasado su "fecha de caducidad").

Hay muchos ejemplos de este escenario un tanto contraintuitivo; en los mercados financieros, por ejemplo, hay estrategias en las que se puede garantizar que un jugador perderá todo el dinero de jugarse permanentemente, pero que podría generar una racha ganadora si se juegan alternativamente ${ }^{15}$.

En el caso de Chile, este escenario se ha hecho bastante evidente, aunque en la estrategia ganadora de la oligarquía se han puesto en práctica más de dos juegos, de modo que su solución matemática implicaría un escenario convexo más complejo que la habitual combinación lineal de dos juegos ${ }^{16}$.

El dilema básico para cualquier oligarquía decidida a mantener tales grados de desigualdad es cómo crear una estrategia ganadora que sea sostenible en una democracia, dado que es una minoría muy pequeña y que el resultado distributivo que procura es tan enormemente desigual.

Lo que se necesita para crear una estrategia ganadora de este tipo a largo plazo es tanto la flexibilidad de cambiar de una estrategia a otra en cuanto pasa a ser contraproducente, como la capacidad para mantener su ideología como hegemónica y solucionar cualquier problema interno de la "acción colectiva" que pueda surgir en el camino para asegurar la cohesión interna, de modo que los miembros actúen conjuntamente, incluso cuando algunas personas pueden tener incentivos para comportarse de manera oportunista (free riders). Este fenómeno a veces se asocia con el concepto de "cierre de élite" (elite clousure). Por su parte, para Adam Smith (1776, Libro 1, Capítulo 5) la mayor capacidad de acción colectiva que tiene la élite la ayuda enormemente a tomar la delantera en el conflicto distributivo.

Estos son componentes cruciales de la capacidad de persistir de la oligarquía. Desde esta perspectiva, North y otros (2007) tenían razón cuando desarrollaron la hipótesis del "orden de acceso limitado": cómo las élites capaces de mantener la cohesión pueden dividirse el control de las rentas y bloquear el acceso de otros.

\footnotetext{
${ }^{15}$ Véase, por ejemplo, Blakeslee (2000).

16 Véase un ejemplo de un juego de tres períodos en Key, Klosek y Abbott (2006).
} 


\section{Estrategia 1. Cómo convertir el resultado probabilístico de un juego distributivo en un escenario determinista en que "el ganador se lleva todo" utilizando el terror}

Cuando Chile eligió un gobierno de izquierda en 1970 -y ese gobierno (algo bien poco común en esta vida) estaba dispuesto a implementar el programa por el que había sido elegido democráticamente, incluido sus aspectos redistributivos (véanse los gráficos 1, 5 y 6) -, la oligarquía chilena, en pánico porque dichas políticas iban a inclinar la balanza en el juego distributivo del gallina a favor de los trabajadores, optaron por la opción nuclear de un golpe de Estado (en un país con una larga tradición democrática).

En otras palabras, la oligarquía optó por transformar el escenario distributivo, de uno en el cual los pobres ganaban terreno, a otro en el que podía implementar su propia estrategia distributiva "preferida" -una, como en el póker, en la que el ganador se lleva todo (winner-takes-all). En este nuevo equilibrio de Nash, con su conjunto particularmente asimétrico de estrategias distributivas, y los pagos correspondientes, un jugador puede convencer a la mayoría de la futilidad de desafiar la situación mientras él tuviera a su disposición toda la maquinaria del terror de Estado.

El resultado de esta nueva estrategia "apetito insaciable" - la "estrategia 1" de la oligarquía en esta narrativa- se muestra claramente en el gráfico 4.

Gráfico 4

Chile: cambios en el porcentaje del ingreso por decil de ingresos, 1973-1987

(En porcentajes)

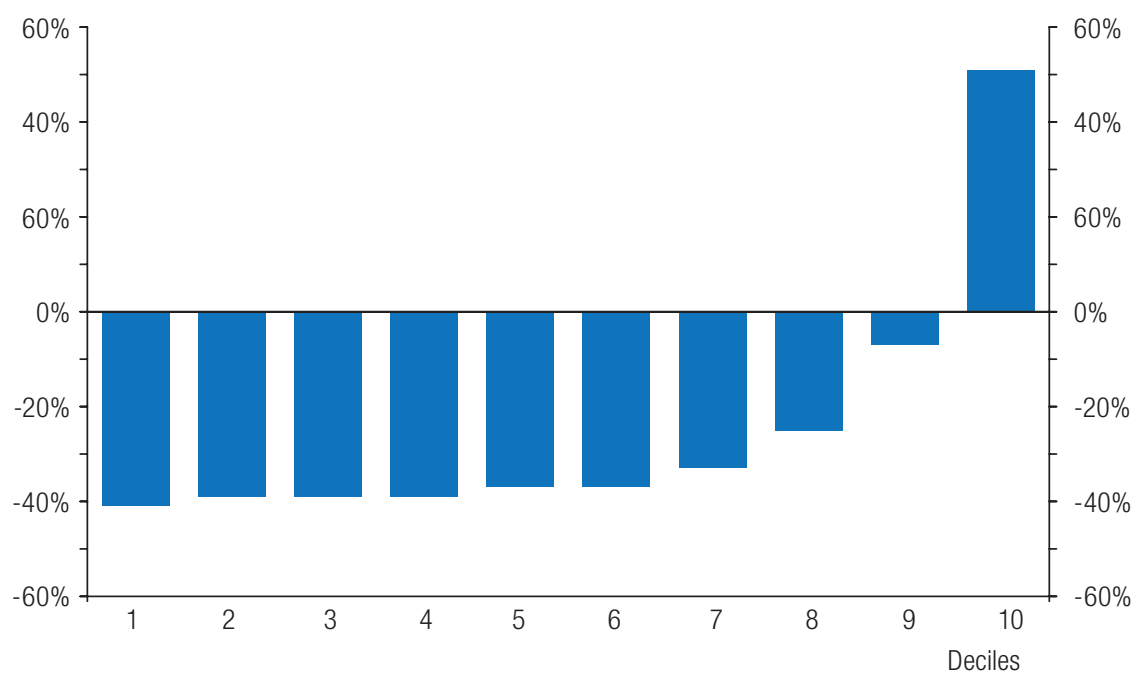

Fuente: Elaborado por P. Jervis y el autor, sobre la base de Centro de Microdatos (CMD), "Encuesta de Ocupación y Desocupación en el Gran Santiago 2019", Facultad de Economía y Negocios, Universidad de Chile, 2020 [en línea] http://documentos. microdatos.cl/Encuestas/Ocupacion/OcupacionDesocupacion?C=T1.

Nota: Los datos se refieren al ingreso per cápita de los hogares en el Gran Santiago (donde vive alrededor del 40\% de la población). Excluye de los ingresos familiares a los allegados y trabajadoras domésticas que viven en la casa, los que declaran ingreso "cero", "no sabe" o "no responden".

De hecho, en esta encuesta la participación del décimo decil aumentó del 34\% del ingreso nacional a no menos del 52\% entre 1973 y 1987 (año en que se llama a plebiscito); incluso le quita participación al noveno decil. Esta situación es parecida a la de un Robin Hood posmoderno, quien no solo roba a los pobres para darle a los ricos, sino que también roba a los ricos para darle a los más ricos... 


\section{Estrategia 2. El retorno a la democracia genera un nuevo desafío para la élite: cómo reconstruir su legitimidad a través de una tecnología del poder más refinada}

Al margen del grado de terror que pudiese ejercer el aparato represor del Estado en dictadura, la oligarquía no podía jugar su estrategia 1 indefinidamente. Inevitablemente, hacia finales de la década de los ochenta, el juego distributivo comenzó a alejarse de su escenario determinista, retornando lentamente a su normalidad probabilística (una con un resultado distributivo más mixto e inestable) debido al creciente malestar popular. Así pues, la estrategia 1 de la oligarquía empezó a volverse contraproductiva (es decir, una estrategia perdedora) porque la mayoría (especialmente las nuevas generaciones) comenzó a perder el miedo a desafiar la estrategia preferida de la oligarquía. El emperador no tenía ropa (solo aparato represivo).

Como salida a este dilema, el Gobierno de Pinochet intentó legitimar su régimen convocando un plebiscito en 1988, que le hubiera permitido seguir siendo el Jefe de Estado por otros ocho años. El Gobierno, a pesar de haber intentado cambiar a última hora algunos de los peores aspectos de su política distributiva (véase el pasaje del punto 3 al punto 4 en el gráfico 7), perdió la votación (y por mucho $)^{17}$.

De hecho, al intentar mejorar sus credenciales democráticas, Pinochet se pegó un tiro en el pie: justo antes del plebiscito, firmó la Convención contra la Tortura y Otros Tratos o Penas Crueles, Inhumanos o Degradantes. Irónicamente, la ratificación de esta convención fue lo que permitió al Juez Garzón de España solicitar al Gobierno del Reino Unido la extradición de Pinochet en 1998. Fue la primera vez que un ex Jefe de Gobierno era arrestado bajo el principio de la jurisdicción universal. Además, y nuevamente por primera vez, esto consagró en el derecho internacional el principio de que la inmunidad de los Jefes de Estado (en ejercicio o anteriores) no se aplica a los crímenes de lesa humanidad.

Cuando Pinochet perdió el plebiscito, y luego sus partidarios también perdieron las elecciones presidenciales y parlamentarias que siguieron por un amplio margen, la élite no tuvo más remedio que cambiar su estrategia distributiva a otra más sofisticada. Y lo hizo con bastante eficacia.

La característica clave de la estrategia 2 es que se parecía a la antigua práctica católica romana de comprar indulgencias, mediante la cual los pecadores (en este caso la oligarquía sacrílega) podían comprar certificados que reconocían que su penitencia los había limpiado del pecado.

Lo fundamental para la oligarquía era recuperar su legitimidad democrática; para ello, qué mejor que apoyar algunas políticas distributivas del nuevo gobierno de centro-izquierda, incluso una reforma fiscal, aunque (con la ayuda de los senadores vitalicios nombrados por Pinochet) consiguieron imponer la condición de que fuera una medida temporal. También apoyaron un aumento del salario mínimo y otras políticas para la reducción de la pobreza, una pequeña reforma de la legislación laboral y otras medidas.

Un componente decisivo de la estrategia 2 fue la necesidad de la oligarquía de reconstruir su alianza distributiva tradicional con los estratos medio y medio-alto, puesto que, como indican los gráficos 4 y 5, también habían salido perdiendo con la estrategia en la que el ganador se lleva todo. Por lo tanto, la oligarquía también apoyó (y presionó) al gobierno de centro-izquierda para que aplicara distintas medidas a fin de beneficiar a este sector. Consecuentemente, la participación de los deciles 5 a 9 en el ingreso recuperó un poco del terreno perdido durante la dictadura, pero luego se

17 En la otra encuesta de hogares (la CASEN), este movimiento del punto 3 al 4 es menos pronunciado. 
estabilizó en un nivel por debajo del 50\% del ingreso nacional, un nivel muy por debajo del que había logrado durante la presidencia de Salvador Allende, lo que indica la dificultad de recuperar terreno perdido en un juego distributivo (véase el efecto de trinquete en el gráfico 5).

\section{Gráfico 5}

Chile: porcentaje del ingreso de los estratos medio y medio-alto, deciles 5 a 9, 1957-2014

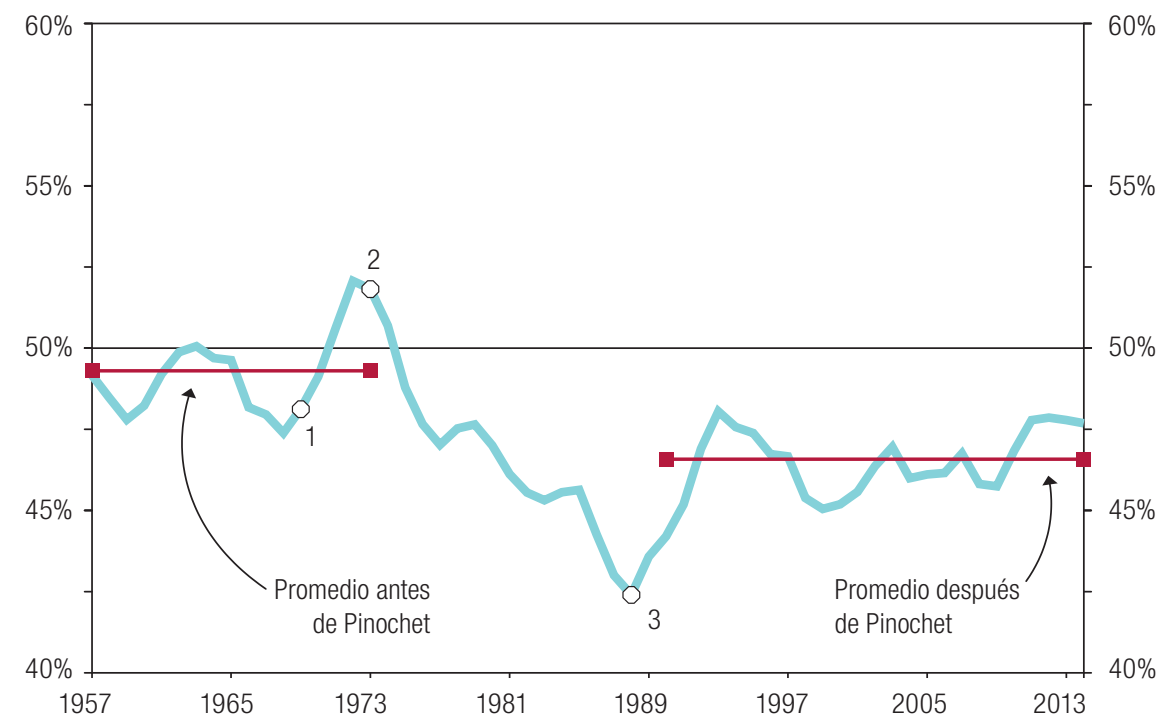

Fuente: Elaborado por P. Jervis y el autor, sobre la base de Centro de Microdatos (CMD), "Encuesta de Ocupación y Desocupación en el Gran Santiago”, Facultad de Economía y Negocios, Universidad de Chile, 2020 [en línea] http://documentos. microdatos.cl/Encuestas/Ocupacion/OcupacionDesocupacion?C=T1.

Nota: Los promedios son medias armónicas (1957-1973 y 1990-2014). Promedios móviles trienales.

1. Elección de Salvador Allende.

2. Pinochet toma el poder en un golpe de Estado.

3. Elección en 1989 del primero de cuatro gobiernos consecutivos de centro-izquierda después de que Pinochet perdiera el plebiscito de 1988, seguidos por un gobierno de derecha en 2010. En la encuesta CASEN, los ciclos después del 3 son menos pronunciados.

El mensaje clave de este gráfico es que Chile es uno de los poquísimos países del mundo donde los deciles 5 a 9 son incapaces de defender su mitad del ingreso nacional (Palma, 2019a). Además, esta imagen no encaja con un escenario acorde a la "elección pública" (public choice theory), donde los agentes toman decisiones en función de sus resultados. Donde estas son "racionales", lo que favorece la lógica, la objetividad y el análisis por sobre la subjetividad y la intuición. En Chile, en cambio, el gráfico 5 indica que los estratos medios (deciles 5 a 9) toman decisiones al margen de sus resultados (como su oposición mayoritaria a Allende, y su apoyo masivo a Pinochet). Quizás la identidad, la subjetividad y la intuición (llamémosle ideología para abreviar) juegan un papel más importante en la toma de decisiones que el economicismo primitivo de Buchanan (¡tenía que haber estudiado en Chicago!).

A su vez, el gráfico 6 muestra los cambios en la participación en el ingreso del 40\% más pobre.

Como sucedió con los estratos medio y medio-alto, la participación del $40 \%$ más pobre se recuperó después del regreso a la democracia. Sin embargo, y a diferencia del trinquete descendente de los deciles 5 a 9 que se muestra en el gráfico 5, durante el período de la estrategia 2 de la oligarquía esta participación volvió a niveles anteriores a 1973 (gracias a las políticas redistributivas de los gobiernos de centro-izquierda dirigidas a la parte inferior de la escala de ingresos). De hecho, cuando la centro-izquierda perdió la reelección en su cuarto intento en 2010 esta participación tenía una tendencia ascendente. 


\section{Gráfico 6}

Chile: porcentaje del ingreso nacional del 40\% más pobre, deciles 1 a 4, 1957-2014

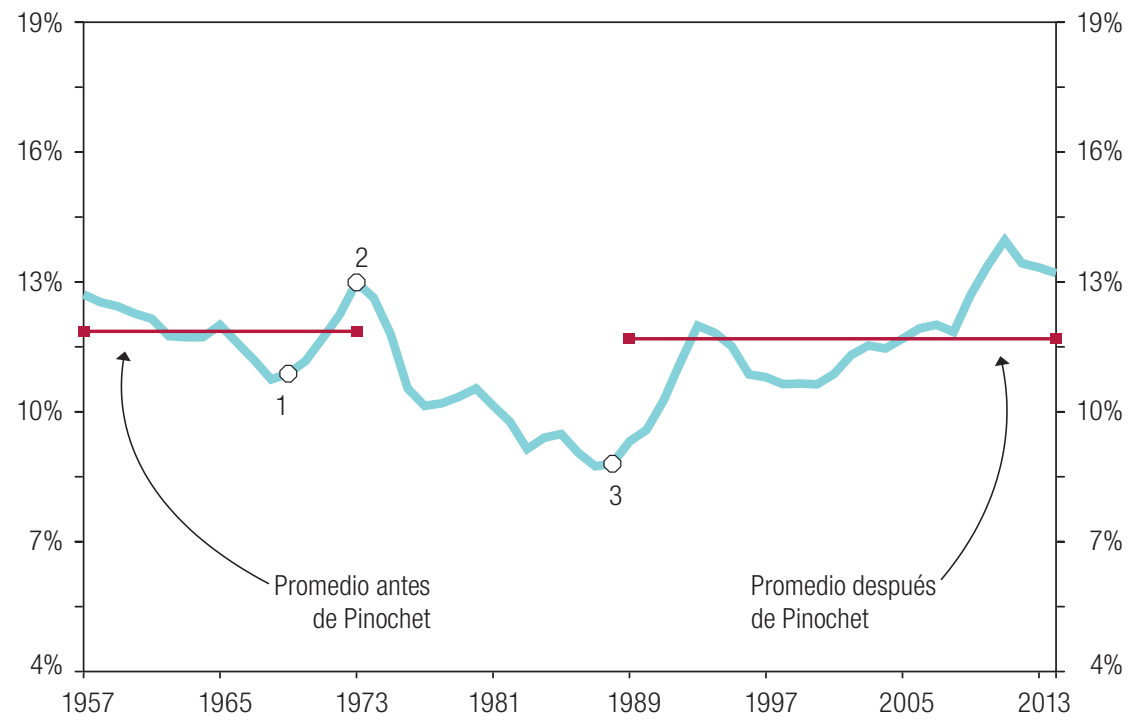

Fuente: Elaborado por P. Jervis y el autor, sobre la base de Centro de Microdatos (CMD), "Encuesta de Ocupación y Desocupación en el Gran Santiago 2019”, Facultad de Economía y Negocios, Universidad de Chile, 2020 [en línea] http://documentos. microdatos.cl/Encuestas/Ocupacion/OcupacionDesocupacion?C=T1.

Nota: Los promedios son medias armónicas (1957-1973 y 1990-2014). Promedios móviles trienales.

1. Elección de Salvador Allende.

2. Pinochet toma el poder en un golpe de Estado.

3. Elección en 1989 del primero de cuatro gobiernos consecutivos de centro-izquierda después de que Pinochet perdiera el plebiscito de 1988, seguidos de un gobierno de derecha en 2010.

En definitiva, la estrategia 2 fue un gran éxito para la élite. Si bien perdió parte de su participación en el ingreso, estos elementos de la estrategia 2 fueron como un sacrificio en una partida de ajedrez, donde perder deliberadamente una pieza puede ayudar a ganar la partida.

Sin embargo, como la oligarquía claramente no tenía ninguna intención de mantener la apariencia de nuevos progresistas indefinidamente, en cuanto consiguió recuperar un mínimo de legitimidad democrática, ya pudo pasar con credibilidad a una nueva estrategia distributiva más agresiva: la estrategia 3.

Por lo tanto, a pesar de que se trataba de una minoría política (pero con la gran ayuda de poder aprovechar el escenario legal hecho a medida por la Constitución de Pinochet y sus "leyes de amarre"), comenzó a adoptar una estrategia más agresiva con acciones como rechazar una nueva reforma laboral (con la ayuda de sus senadores designados), y revertir la reforma fiscal del primer gobierno democrático ${ }^{18}$.

Resulta sorprendente cómo la oligarquía, con el apoyo de sus aliados militares, consiguiera relegitimizar su ideología como hegemónica, pero ahora en democracia. La pregunta clave es: ¿cómo fue posible?, ¿cómo pudieron crear un consenso hegemónico en torno a su discurso de la supremacía del mercado desregulado y la economía de chorreo?, ¿y por qué la "nueva" izquierda no solo fue neutralizada ideológicamente, sino que, además, fue seducida a defender esta transformación? (Quizás, "si no puedes vencerlos, únete a ellos").

\footnotetext{
${ }^{18}$ Esto en un país donde, incluso con dicha reforma, la recaudación fiscal oscilaba alrededor del 20\% del PIB (OCDE, 2020b), y donde cuanto más alto era el decil de renta, menor era la proporción de ingresos que se pagaba en impuestos (véanse Engel, Galetovic y Raddatz, 1999, y López y Miller, 2008). Además, como en el resto de América Latina, la evasión del pago del impuesto sobre la renta era sideral; la CEPAL (2016) calculó que la evasión fiscal representaba casi el 7\% del PIB regional.
} 


\section{Estrategia 3. ¿Cómo pudo surgir en democracia algo que se asemeja a un equilibrio de Nash en torno a la estrategia distributiva preferida de la élite, con su extrema desigualdad y sus pagos unilaterales?}

El primer objetivo clave de la estrategia 3 era estabilizar el resultado distributivo de la estrategia 2; su lema era jno más concesiones! El segundo era consolidar la ideología de la oligarquía como la indiscutidamente hegemónica. Cuando se lograron ambos objetivos, lo que coincidió con las primeras etapas de la segunda presidencia de la centro-izquierda, la oligarquía pudo finalmente sacarse la máscara y volver a distorsionar la desigualdad a su favor (ahora en democracia). El gráfico 7 resume el resultado de estas tres estrategias distributivas de la oligarquía; la 1, o el crecimiento de la desigualdad amparada por el terror; la 2, o el proceso de relegitimación del capital; y la 3, sustentar la mayor desigualdad amparados en una tecnología más refinada de poder, basada en formas más sofisticadas de dominación ${ }^{19}$.

El notable éxito de la oligarquía durante los primeros años de la "estrategia 3" tiende a confirmar mi hipótesis de que el neoliberalismo bien puede haberse convertido en una de las tecnologías del poder más eficaces de la historia. En América Latina, la ideología neoliberal -con su relegitimación del capital, que tanto éxito tuvo- pasó a hacer referencia al arte de salirse con la suya: la legitimación de una desigualdad obscena e ineficiente en democracia. O, en la jerga de la teoría de los juegos, se convirtió en una tecnología del poder capaz de transformar un conjunto particularmente asimétrico de decisiones estratégicas distributivas, y los correspondientes pagos unilaterales, en algo que se asemeja a un equilibrio de Nash en democracia -aunque una de poca intensidad-. Y lograba hacer esto convenciendo a la mayoría de que era inútil intentar desafiar esta situación mientras los jugadores de altos ingresos (dueños de la cancha, del reglamento y de la pelota) no cambiaran su estrategia.

Era inútil desafiarlo no solo porque las probabilidades de conseguir tener éxito eran mínimas (dada la naturaleza distorsionada del contexto en el cual se desarrollaba el juego), sino también porque la mayoría tenía que entender que su magro pago era su suerte en la vida. En todo caso, teniendo en cuenta el panorama nacional e internacional del momento, ese tipo de neoliberalismo era la única opción viable. Además, como nos recuerda Adorno (1951), la dominación es mucho más efectiva si la oligarquía "puede delegar la violencia en la que se basa en los dominados" (de centro-izquierda).

Como resultado, el juego distributivo incluso dejó de ser un juego del "gallina" y se convirtió en uno en el que este equilibrio de Nash en torno a la estrategia 3, algo tan improbable en democracia, fue posible principalmente por convicción ideológica. El hecho más destacable fue que el neoliberalismo como tecnología del poder pudo hacer esto sin la necesidad de emplear los antiguos métodos burdos para la resolución de los conflictos sociales. En otras palabras, la oligarquía finalmente consiguió lograr en democracia lo que antes solo era posible en dictadura.

19 Véase también el gráfico 9. 


\section{Gráfico 7}

Chile: impactos distributivos de las estrategias 1, 2 y 3 (índice de Palma), 1957-2010

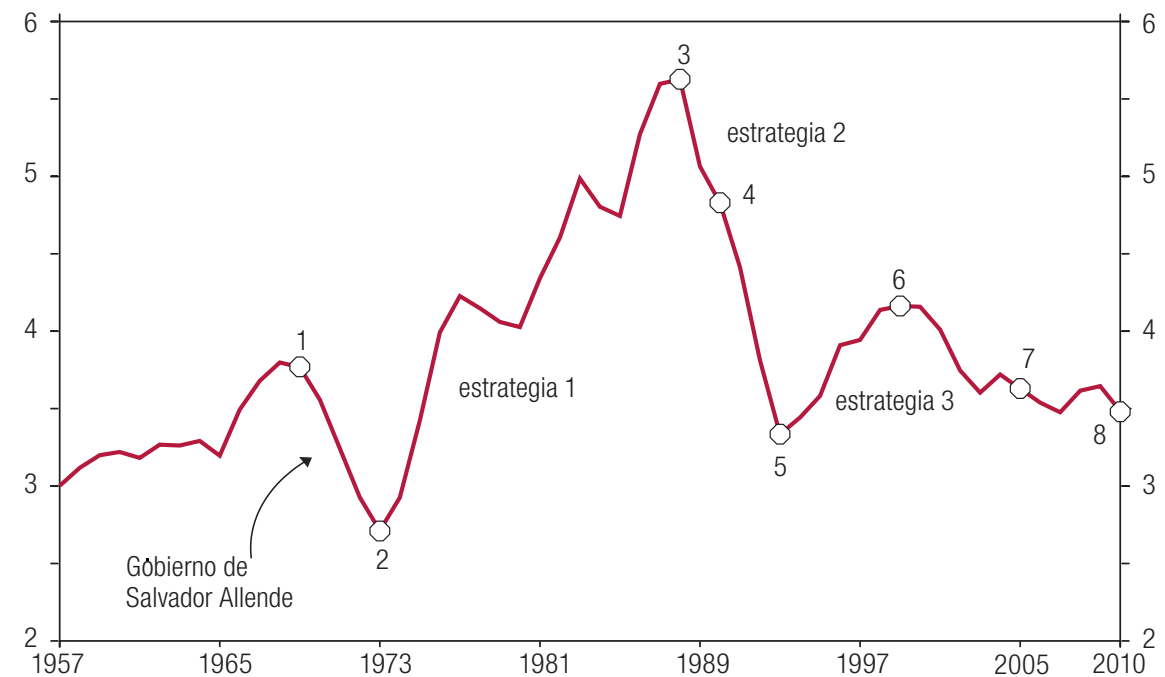

Fuente: Elaborado por P. Jervis y el autor, sobre la base de Centro de Microdatos (CMD), "Encuesta de Ocupación y Desocupación en el Gran Santiago 2019", Facultad de Economía y Negocios, Universidad de Chile, 2020 [en línea] http://documentos. microdatos.cl/Encuestas/Ocupacion/OcupacionDesocupacion?C=T1.

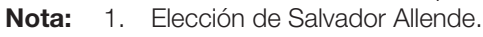

2. Estrategia 1 (a continuación del golpe de Estado).

3. Estrategia 2 (desde la convocatoria del plebiscito de 1988 hasta comienzos del segundo gobierno de centro-izquierda).

4. Primer gobierno democrático (coalición de centro-izquierda).

5, 6 y 7. Estrategia 3 (consolidación de la desigualdad durante los siguientes tres gobiernos de centro-izquierda).

8. Primer gobierno democrático de derecha en más de medio siglo. Promedios móviles trienales 20

Este fue un gran logro -mientras duró-. Cuando la mayoría vuelve a desafiar dicho equilibrio Nash en torno a la estrategia preferida de las élites, en varios países estas modificaron sus estrategias buscando alianzas con una variedad de causas paralelas -como con guerras culturales, racismo, misoginia, nativismo, xenofobia, nacionalismo, agendas religiosas moralistas y cualquier posible causa populista; y en ocasiones el crimen organizado también ayudaba. El apoyo de las élites corporativas y financieras a proyectos como el de Trump y Bolsonaro es paradigmático.

En Chile, sin embargo, esas causas auxiliares generaban poca tracción; además, una élite algo más sofisticada políticamente todavía podía salirse con la suya usando formas más tradicionales de dominación, como el poder de seguir debilitando al resto de la sociedad imponiendo una vida cada vez más insegura a los trabajadores y al Estado. Estas acciones representaban el látigo, mientras que la zanahoria era la promesa de que la retribución para la mayoría en algún momento mejoraría gracias a los efectos de goteo. Y tenían que ser razonables porque no había ninguna alternativa factible que fuese mejor para ellos.

Finalmente, la élite en forma inteligente no se opuso a la nueva agenda valórica de los gobiernos de centro-izquierda, que incluía el derecho al aborto y a la igualdad legal de las personas homosexuales, a pesar de ser totalmente antagónicos con sus valores morales. De hecho, la derecha se opuso en forma mucho más tenaz a una reforma tributaria menor impulsada por el cuarto gobierno de la centro-izquierda que al proyecto que legalizaba en ese momento el aborto en tres causales. Lo último fue solo un saludo a la bandera...

\footnotetext{
20 Para ver un video que explica la naturaleza del coeficiente de Palma como un nuevo índice de la desigualdad, publicado originalmente en el Washington Post, véase Uncounted, "The Palma" [en línea] http://uncounted.org/palma/. Véase también [en línea] https://www.youtube.com/watch?v=wY9XFQA-McA\&feature=youtu.be. Siguiendo la lógica del coeficiente de Palma, el Banco Mundial (2016) acuñó una estadística conexa, la "prima Palma" (Palma premium), un índice que se asemeja a la primera derivada del coeficiente de Palma (ya que indica la dirección del cambio en la desigualdad).
} 
De esa manera, Chile pudo deshacerse de la imagen de república bananera donde la oligarquía necesitaba personajes siniestros, tanto en política como en el manejo de la economía, para lograr sus objetivos. En su nuevo y más sofisticado modelo de dominación, los regímenes militares -la tradicional salvaguarda (hedge) contra la amenaza de la mayoría - podían volverse obsoletos. El neoliberalismo en su máxima sofisticación.

El rápido crecimiento económico durante este período (el de la estrategia 2 y comienzos de la 3, véase el gráfico 8) respalda la hipótesis (antifundamentalista) de Díaz Alejandro (1983), quizás la mayor contribución que jamás haya hecho un latinoamericano a la teoría económica: con respecto al éxito de las políticas económicas, importa tanto su naturaleza como el grado de apoyo que consigan.

Mientras tanto, la mayoría de mis colegas se pasan la vida discutiendo las bondades absolutas de sus propuestas, ignorando esta simple verdad. Pero cuando solo la ideología es el leitmotiv de tantas ideas...

Desde esta perspectiva, el verdadero desafío para la élite capitalista era que para mantener la estrategia 3 -y ese grado de apoyo- tenía que seguir generando un alto nivel de crecimiento económico y "goteo". Es decir, para seguir "fabricando consentimiento" (Herman y Chomsky, 1988), esta élite tenía que demostrar que su modelo podía generar progreso y bienestar en forma sustentable.

Sin embargo, la realidad inevitablemente pasó la factura a la estrategia 3, ya que en una economía capitalista desregulada y con tan pocas compulsiones (en especial de mercado), el crecimiento estaba destinado a desacelerarse por el predominio de las rentas "fáciles", y con él (a la luz de la persistente desigualdad) también los efectos de goteo ${ }^{21}$. De esta forma, el crecimiento del PIB, y en especial el de la productividad, se desaceleraron rápidamente a pesar de condiciones externas muy favorables a partir de 2002 en adelante (en especial en el precio de las exportaciones y el fácil acceso a endeudamiento barato). De hecho, el crecimiento de la productividad se desaceleró del 3,9\% anual durante los años dorados de este modelo (entre 1986 y 1998) a solo el 0,4\% en la década anterior al estallido social (véase el gráfico 8).

No hay duda de que en términos del efecto de goteo y el bienestar de la mayoría, la estrategia 3 falló estrepitosamente: en un país que había alcanzado un PIB per cápita de 15.000 dólares (o 25.000 dólares expresados en paridad del poder adquisitivo; Banco Mundial, 2020), tal grado de desigualdad significaba que en las etapas finales de la estrategia 3, el salario neto mediano chileno no era suficiente para mantener por encima del umbral de la pobreza a una familia de cuatro personas. Y, como es de esperar en este tipo de situación, esa mediana esconde una enorme brecha de género: en promedio, las mujeres ganaban un $28 \%$ menos que los hombres, por lo que en este caso casi dos tercios de los hogares de este tipo estarían en esta situación²2.

Teniendo esto en cuenta, un aspecto sorprendente de este equilibrio de Nash tan improbable que se logró con la estrategia 3 -y en democracia- es que, mientras existió, la mayoría perfectamente podría haber mejorado su pago si hubiera acordado (manteniendo un mínimo de acción colectiva) una estrategia diferente. Pero los partidos políticos de centro-izquierda, a pesar de contar todavía con el apoyo de la mitad de la población, no estuvieron a la altura de este reto.

De hecho, la idea de que no existían alternativas estaba muy arraigada en el consenso hegemónico alrededor de la estrategia 3 y sintetizaba el cimiento del discurso neoliberal al estilo angloibérico. Esta idea (la cual llegó a tener un carácter de tabú) tuvo un sorprendente efecto paralizador en la "nueva" izquierda y en la mayoría de la población.

En lenguaje freudiano, el tótem construido en torno al poder supremo de los mercados desregulados, que les daba un significado casi sobrenatural-como un símbolo erigido como emblema

\footnotetext{
${ }^{21}$ Sobre por qué el capitalismo necesita para su dinámica mercados que generen compulsiones véanse especialmente Wood (2002) y Khan (2005).

22 Véase Durán y Kremerman (2020).
} 
de la tribu neoliberal, la cual se había convertido a una especie de religión animista-, junto con el tabú que impedía incluso imaginar alternativas (después de todo, jera el fin de la historia!), es una de las estratagemas ideológicas más efectivas de todos los tiempos.

Seguramente Gramsci se sintió reivindicado. En una democracia, los conflictos distributivos básicamente se ganan o se pierden a nivel de la ideología (apoyada por el poder de la movilización social). ¿Fundamentos? ¡Qué fundamentos!

Además, como enfatizó Albert Einstein (y Poulantzas (1975), que siguiendo a Althusser, luego teorizó), incluso en las ciencias naturales "el poder de observar una cosa o no depende de la teoría que uses. Es la teoría lo que indica lo que se puede observar"23. En economía esta teoría también sugiere el rango de opciones para la especificación econométrica, y el círculo se puede cerrar fácilmente, ya que en los ejercicios econométricos tradicionales existe el problema del "demasiado grande para fallar" (too big to fail); es decir, en muestras muy grandes, los valores "p" disminuyen rápidamente a cero. Esto puede inducir a los investigadores a afirmen erróneamente que su econometría respalda hipótesis que no tienen relevancia práctica.

\section{La fuerza y la debilidad de la estrategia 3}

Una de las interrogantes más profundas de todo esto es por qué la estrategia 3 no pudo ser sustentable. Comenzando por sus aspectos ideológicos, la fuerza y la debilidad de algunas de las ideas del discurso neoliberal no es tema nuevo. Por ejemplo, ya eran evidentes en un argumento de Calicles (un personaje en el diálogo de Platón Gorgias): "Es natural y justo que los fuertes dominen a los débiles, y... es injusto que los débiles se resistan a tal opresión estableciendo leyes para limitar el poder de los fuertes"24.

En opinión de Calicles -como en la crítica neoliberal del estado del bienestar socialdemócrata de posguerra-, el problema (y lo que había que cambiar) era que "Ios más fuertes, más agresivos y dominantes por naturaleza habían sido debilitados y domesticados por las nuevas instituciones jurídicas del débil demos"25.

Calicles incluso intenta disuadir a Sócrates de filosofar:

"Ciertamente, Sócrates, la filosofía tiene su encanto si se toma moderadamente en la juventud; pero si se insiste en ella más de lo conveniente es la perdición de los hombres. Hazme caso: cesa de argumentar, cultiva el buen sentido de los negocios y cultívalo en lo que te dé reputación de hombre sensato. (...) Imita, no a los que discuten irrelevancias, sino a las personas de sustancia y honor, y que además tienen éxito material en la vida."26

En resumen -y de la misma forma que a la élite capitalista le gustaba predicar a la "nueva" izquierda durante la transición a la democracia-, deja de filosofar, abandona el argumento, pon los pies en la tierra, haz un MBA. También ayuda el convencer al resto de la sociedad de que el bando de los "disidentes" solo estaba compuesto por dogmáticos pedantes.

El componente debilitante de este discurso para las fuerzas progresistas vulnerables a la pandemia neoliberal es que abandonar la filosofía y la argumentación realmente significaba dejar de pensar de

\footnotetext{
${ }^{23}$ Citado en Heisenberg (1971, pág. 63). Además, "[...] como ha enfatizado Einstein, [...] la deducción en el método [científico] no va de los hechos a la teoría, sino de la teoría a los [...] datos. En consecuencia, las teorías deben proponerse especulativamente y seguirse deductivamente con respecto a sus múltiples consecuencias para que puedan ser puestas [...] a prueba. En síntesis, cualquier teoría [...] hace más [...] suposiciones filosóficas de las que los hechos por sí solos dan o implican” (Northrop, 1958).

24 Véase [en línea] https://www.gutenberg.org/files/1672/1672-h/1672-h.htm.

25 Ibíd.

26 Ibíd.
} 
modo crítico ${ }^{27}$. El problema con el pensamiento crítico, por supuesto, es que es una actividad que distancia e incluso debilita. Nos distancia de las convenciones, de las suposiciones implantadas y de las creencias establecidas. Toma lo que sabemos de los contextos conocidos e incuestionables y lo convierte en algo extraño. Y lo hace no solo proporcionando nueva información, sino fomentando y provocando una nueva forma de ver.

El riesgo es que una vez que lo familiar se vuelve extraño, ya nunca vuelva a ser lo mismo. Por inquietante que sea, no hay vuelta atrás -nunca puede ser despensado ni desconocido-. Y como muchos de la izquierda en América Latina saben demasiado bien, también implica enormes riesgos, tanto políticos como personales. Una manera de evitar esos riesgos (sobre todo, después de tantas decepciones y tanto terror) es a través de la evasión: el escepticismo. Aunque, como nos recuerda Immanuel Kant (1998), si bien un período de escepticismo puede ser un lugar de reposo para reflexionar sobre previas andanzas dogmáticas, permanecer en él es sencillamente abandonar la reflexión moral.

La cuestión aquí, por supuesto, es que a pesar de los delirios supremacistas de la oligarquía derivados de algún autoconvencimiento de supremacía moral, los más fuertes no lo son por naturaleza, sino por entorno. Este es un tema fundamental de la reflexión darwiniana del progreso, que afirma que un subconjunto de miembros de una población puede llegar a prosperar en comparación con otros miembros sencillamente porque poseen una característica, de la que carecen los demás, que hace que puedan estar mejor adaptados a un entorno local específico. La cuestión del valor intrínseco de los que más prosperan no es parte de esta narrativa (Lawson, 2003).

Esto nos lleva a un componente central de mi forma de entender el significado profundo del neoliberalismo: un intento consciente y deliberado de crear un entorno económico específico, el cual se construye artificialmente, donde las características que posee el capital, y que no poseen los demás, sean las favorecidas. Un entorno en el cual un agente móvil y maleable puede llegar a ejercer un dominio incontestable -y que, además, su éxito luego cree una fuerza seductora que fomente esta ideología.

Siguiendo al dilema que presenta Hirschman (1970) entre "salida, voz y lealtad" (exit, voice, and loyalty), se podría argumentar que una de las razones de este dominio de la élite capitalista es que, en ese escenario, son los únicos que tiene una opción de salida creíble: el acceso fácil a activos financieros móviles les proporciona una estrategia de salida factible. Por lo tanto, las amenazas que hace en el juego distributivo son aún más creíbles en esas circunstancias. Aquí podemos pensar en la metáfora de alguien que al jugar un partido de fútbol les dice a los otros jugadores que él jugará de centro-delantero o se irá a casa y se llevará el balón. Sin duda, no es el mejor escenario para formar un equipo eficaz.

Otra metáfora sería la de un rompecabezas donde algunas piezas grandes pueden decidir a gusto qué forma quieren tener, mientras que el resto tiene que cambiar su forma para encajar. $O$, según el gran dibujante argentino Quino, es como una partida de ajedrez en la que la oligarquía puede hacer jaque mate a sus oponentes cuando quiera, independientemente de cuál sea su posición en el tablero (lo que además haría que el juego fuera bastante aburrido y fácil de predecir su ganador) ${ }^{28}$.

Sin embargo, por lo menos tener una estrategia de salida fácil es justamente lo que ayuda a las oligarquías latinoamericanas a ser más democráticas -pueden correr el riesgo porque en el nuevo orden internacional ya no necesitan estar atadas geográficamente a las inversiones fijas, como la tierra en el pasado-29.

Aunque el núcleo de su acumulación será siempre su país de origen (como el lado puramente extractivo de los recursos naturales y algunas actividades como las finanzas nacionales) -difícil que encuentren otros lugares con estos niveles de rentabilidad-, ahora pueden hacer negocios

\footnotetext{
27 Véase Palma (2016b).

${ }^{28}$ Véase [en línea] http://ajedrezenlaunla.blogspot.com/2012/04/quino-y-el-ajedrez.html.

29 Véanse Boix (2003) y Palma (2019a).
} 
cómodamente con una cartera diversificada desde el punto de vista geográfico. Así, mientras más plata tengan en paraísos fiscales, mejores mansiones en Palm Beach (ojalá lo más cerca posible de Mar-a-Lago), y más inversiones en países vecinos, más creíbles son sus amenazas en el juego distributivo nacional.

En Chile, por ejemplo, y según las estadísticas de la balanza de pagos, los activos de la posición internacional de inversión del sector privado financiero y no financiero (sin contar los fondos de pensiones privados) alcanzaron los 383.000 millones de dólares en 2018 , aproximadamente un tercio más que el PIB de ese año (Banco Central de Chile, 2020). Y el componente de divisa extranjera en la deuda global de las corporaciones no financieras alcanzó un tercio del PIB (unos 100.000 millones de dólares); con la excepción de China, la más grande de todas las economías emergentes (como participación del PIB) (Avdjiev, McGuire y von Peter, 2020). Aunque contrariamente a lo que sucede en China, esto apenas se refleja en la inversión nacional, la absorción tecnológica, la diversificación productiva y el crecimiento de la productividad, pues en lugar de invertirlos en casa, la mayoría de estos fondos se utilizaron para financiar la fuga de capitales y trasladar capacidades productivas a países vecinos.

Así pues, los activos surgieron en el exterior mientras que las deudas se mantuvieron en el país; y como les enseña la historia, con garantías gubernamentales implícitas a las cuales se han acostumbrado.

Esta estrategia de "desarrollo" ya estará obsoleta, y hace mucho, pero hasta el estallido social en 2019 era sustentada por una configuración política un tanto extraña, caracterizada por la interacción de una élite capitalista insaciable (pero adversa al riesgo en materias productivas; o, como diría Keynes, sin "espíritu animal" (animal spirits)), una intelligentsia progresista capturada, ciudadanos pasivos y una imaginación social paralizada por las certezas absolutas de la ideología hegemónica dominante, los fantasmas del pasado, y los desastres de experimentos alternativos en la región (Palma, 2016a).

Otro componente útil para la dominación oligárquica en todo esto es el hecho de que, en la tradición iberoamericana, las sociedades suelen estar dirigidas por enormes maquinarias del Estado formadas por burócratas anónimos preparados para seguir pasivamente cualquier ideología que esté a la orden del día, sin importar cuán económicamente ineficiente dicha ideología sea. La administración pública en estos países es muy diferente de las weberianas, como la de la República de Corea, la provincia china de Taiwán o Singapur (entre otras).

De hecho, un ejemplo paradigmático en Chile de este síndrome iberoamericano del burócrata anónimo es la forma en que negociaron el Tratado Integral y Progresista de Asociación Transpacífico (comúnmente llamado TPP-11) los burócratas pertinentes ${ }^{30}$, quienes parecían convencidos de que su función profesional era limitarse a seguir las directrices de la ideología dominante. Como subraya Primo Levi (1986), las personas verdaderamente peligrosas son "los funcionarios dispuestos a creer y actuar sin preguntar".

En resumen, en la estrategia 3 solo podía haber un ganador distributivo; la elevada tasa de crecimiento económico en los noventa, los beneficios del chorreo de las distintas burbujas financieras (incluida la residencial) y el fácil acceso al crédito contribuyeron a confirmar el potencial de la estrategia 3, y propiciaron el apoyo popular al discurso de la supremacía del mercado desregulado.

Este apoyo incluso continuó después que la economía se desaceleró y se redujo el chorreo. Tanto es así que los partidos de derecha incluso consiguieron ganar una elección presidencial por primera vez en más de medio siglo después de más de una década de desaceleración económica. Parece que las memorias del éxito tienden a durar más que la de los fracasos, como un sistema de expectativas adaptativas en el cual lo primero (los éxitos) tiende a generar una memoria que persiste más en el tiempo.

30 Véase Palma (2018). 


\section{Las limitaciones del capitalismo rentista: de la estrategia 3 a la 4}

Ya decía en la dedicatoria de este artículo a Maradona, y como nos enseñaba Freud, nuestras fuerzas vitales se mezclan con nuestro instinto de autodestrucción. En Chile, igual que en todo el mundo embriagado por las certezas absolutas de la ideología neoliberal, el paraíso para la élite asociado a la estrategia 3 fue temporal. Por su propia naturaleza, la élite tampoco tenía una gran probabilidad de ganar indefinidamente con esta estrategia.

En las palabras de Abraham Lincoln, un talón de Aquiles de la estrategia 3 era que "puedes engañar a todo el mundo algún tiempo; puedes engañar a algunos todo el tiempo; pero no puedes engañar a todo el mundo todo el tiempo", diciéndole que no hay alternativa. La desaceleración del crecimiento y del efecto de goteo tenían eventualmente que ejercer un papel decisivo. El estallido social de octubre de 2019 finalmente puso punto final a la estrategia 3. Había logrado sus objetivos para la élite, pero se había vuelto contraproductiva y finalmente se ahogó en un tsunami de descontento.

La pregunta fundamental es por qué el mismo éxito de la estrategia 3 fue su peor enemigo. Para mí la clave ya está en Ricardo: la limitación natural de un capitalismo tan "cómodo" y rentista como ese (lo que he llamado cosy-capitalism, Palma (2019b)) es que la élite capitalista empieza a dar por sentada esa comodidad. La supremacía de las rentas "fáciles" (en desmedro de las utilidades operativas por hacer algo socialmente útil) lleva a que la inversión, la diversificación productiva, la absorción de tecnología y el crecimiento de la productividad, entre otros, se conviertan en extras opcionales (véase el gráfico 8). Para la élite, su enorme participación en el ingreso nacional pasa a ser una fuente de diversión (lo que incluye el casino financiero y la fuga de capitales), en lugar de ser el combustible que impulsa los nuevos motores del crecimiento de la productividad.

También hay que seguir produciendo pobres (ya sea nacionales o importados como inmigrantes), pues como nos dice Voltaire en el epígrafe, la comodidad de unos también depende de la abundancia de los otros.

Ya nos decía Keynes (1920) analizando el éxito de las economías emergentes de fines del siglo XIX, como Alemania y los Estados Unidos: "Los nuevos ricos del siglo XIX ... preferían el poder que les daba la inversión por sobre los placeres del consumo inmediato. ... Aquí yace, de hecho, la principal justificación del sistema capitalista. Si los ricos hubiesen gastado su nueva riqueza en su propio goce, un régimen así se hubiese hecho hace mucho intolerable".

Sí, ¡iciertamente intolerable! Ahí, precisamente, está el mayor desafío del neoliberalismo como tecnología de poder: quiere hacer lo contrario a todo aquello, pero transformar lo (inevitablemente) intolerable en tolerable -y en democracia-.

El gráfico 1, 4 y 7 ya resumía el éxito distributivo de la estrategia 3. El gráfico 8, por su parte, muestra sus repercusiones en la economía real: en el capitalismo "cómodo" y rentista, la comodidad para la élite y los desafíos de los mercados dinámicos no son buenos compañeros de ruta. El "cronismo" (o las relaciones cada vez más estrechas y mutuamente ventajosas entre los líderes empresariales y los funcionarios de los gobierno de centro-izquierda) tampoco ayudó, ya que facilitó la transformación de la estrategia 3 en una versión extrema del capitalismo de "orden de acceso limitado" de North ${ }^{31}$.

\footnotetext{
${ }^{31}$ North y otros (2007).
} 


\section{Gráfico 8}

Chile: PIB, empleo y productividad, 1950-2019

(En porcentajes)

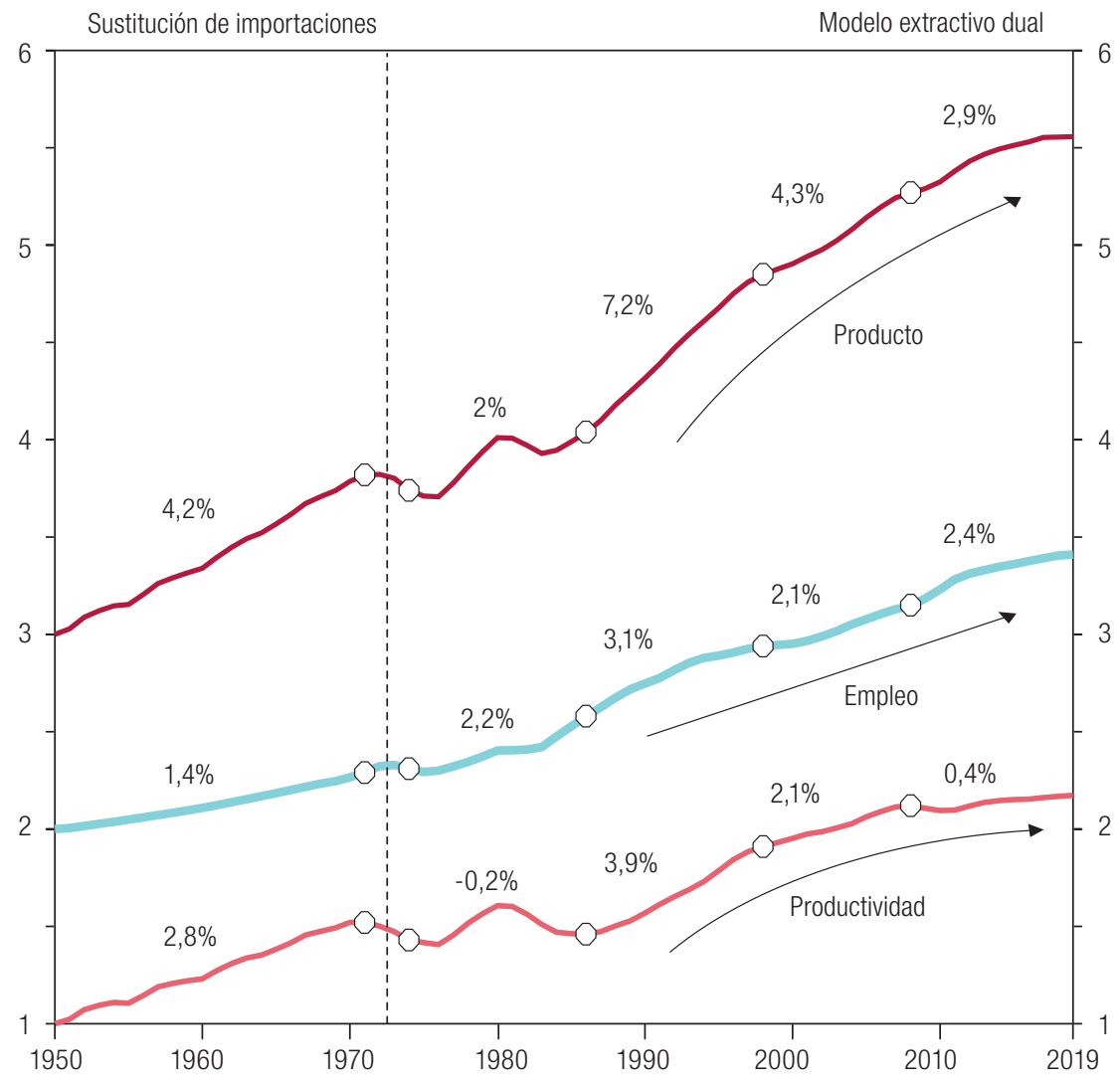

Fuente: The Conference Board, "Total Economy Database: key findings", 2020 [en línea] https://www.conference-board.org/ data/economydatabase/.

Nota: Cada serie es un número índice (escala logarítmica), con base 1 en 1950 para la productividad, base 2 en 1950 para el empleo y base 3 en 1950 para el PIB. El modelo extractivo dual es la forma en que llamo a la estrategia de desarrollo que siguió Chile a partir de sus reformas económicas neoliberales ${ }^{32}$. La productividad se refiere al producto por trabajador. Promedios móviles trienales.

El gráfico 8 confirma la idea de que si bien el neoliberalismo pudo haberse convertido en una de las tecnologías de poder más eficaces de la historia, tuvo sus talones de Aquiles: su preferencia por un escenario económico en el que hubiera pocas compulsiones de mercado para el gran capital. La supremacía de las rentas de ineficiencia, como las provenientes de las fallas y distorsiones de mercado, también requería de un Estado "subsidiario", que en lugar de "disciplinar" a la élite capitalista por ejemplo, (a invertir una alta proporción de sus ingresos en actividades con alto potencial de crecimiento de la productividad en el largo plazo), es "disciplinado" por dicha élite. En otras palabras, como expresara un dirigente empresarial, Chile se transformó en una economía de mercado solo de nombre (Lamarca, 2009). Un "capitalismo" de este tipo (rentas fáciles para le élite, capitalismo para los demás), llevó inevitablemente al estancamiento del crecimiento de la productividad -el cual terminó con un crecimiento promedio de apenas el 0,4\% por año en algo más que la década anterior al estallido social de 2019, cifra similar al promedio de la región desde 1980. Lo que diferencia a Chile del resto de la región es simplemente que tuvo su período extractivista de oro en los noventa, pero luego desperdició dicha energía.

32 Véase Palma (2019b). 
Si lo que quieres es capitalismo, como insistió Keynes, debes protegerlo de este tipo de capitalistas meramente rentistas implementando estrategias alternativas de desarrollo y de autonomía nacional. Para eso se requiere un Estado que procure inyectar dinamismo en la economía (Libro 1 de la Teoría General, Keynes (1936)), y que ayude a coordinar la inversión (capítulo 12). Esto es, para ello se necesita un Estado "disciplinador" y no "disciplinado". Esta es la clave del éxito de las economías emergentes de Asia $^{33}$. Pero en el Chile de la estrategia 3, con su Estado "disciplinado-subsidiario", no había rastros de tal agenda de desarrollo.

Como muestra el gráfico 8, el crecimiento del PIB se desaceleró rápidamente durante el período de la estrategia 3, debido casi por completo al desmoronamiento del crecimiento de la productividad (de un promedio del 3,9\% al año a apenas el 0,4\%); es decir, hasta el punto de que la creación de empleo barato (principalmente en los sectores de servicios tradicionales y la construcción, que representaban el $80 \%$ de la fuerza de trabajo, con su tradicional bajo potencial de crecimiento de la productividad a largo plazo) pasó a ser el único motor del crecimiento del PIB para este capitalismo cada día más "confortable" para la élite. El impacto político y económico de esto fue abrumador, y dio la razón a Krugman (1994): "[el crecimiento de] la productividad no lo es todo, pero, a la larga, lo es casi todo".

Tanto es así que cuando el país inevitablemente se quedó sin mano de obra barata -porque los servicios tradicionales y la construcción la habían absorbido a un ritmo entre dos y tres veces superior al (bajo) crecimiento de la población-, la élite capitalista tuvo que enfrentar una encrucijada histórica. Era exactamente la misma encrucijada en la que se habían encontrado los países hoy desarrollados cuando tenían un nivel de desarrollo similar. En esta había dos alternativas: hacer frente a la escasez de mano de obra barata, y la inevitable subida de los salarios, subiendo la productividad actualizando la estrategia de desarrollo -en el caso de Chile sería modernizando su modelo extractivo dual buscando nuevos motores de crecimiento de la productividad, como la industrialización de los recursos naturales o un nuevo pacto verde-. La otra alternativa era simplemente optar por el "más de lo mismo", rellenando el mercado de trabajo con mano de obra barata a través de una nueva política de inmigración masiva proveniente de los países vecinos.

Fácil es adivinar lo que ocurrió en el capitalismo cómodo y placentero de la estrategia 3. En lugar de acelerar el crecimiento de la productividad se prefirió el "más de lo mismo" con abundante mano de obra barata. La afluencia masiva de inmigrantes que siguió (hasta ahora equivalente a alrededor del $10 \%$ de la fuerza laboral) fue generada por incentivos desde Chile, no por factores externos que la impulsaran (por pull, no por push factors). Es decir, comenzó con cambios deliberados en la política de inmigración, no con disturbios políticos en los países vecinos.

La mayoría de los inmigrantes llegaron legalmente, en avión al aeropuerto principal de Santiago (a menudo en vuelos contratados a tal fin). Este fenómeno creó un paraíso para las bandas dedicadas a la trata de personas, que organizaron la logística, el transporte y los trámites, y luego se aprovechaban de las terribles condiciones en que muchos de esos inmigrantes terminaban viviendo en Chile. Lo único que necesitaban los inmigrantes para conseguir un visado de turista al llegar a Chile era el billete de avión de regreso, un documento de identidad y algo de dinero en efectivo (para probar que eran "turistas") -todo esto lo solían proporcionar las mismas bandas de traficantes-. Luego con un contrato de trabajo que, de nuevo, a veces la proporcionaban las mismas bandas, bastaba para cambiar la visa de turista por un permiso de residencia y trabajo.

Además, nadie de los que impulsaron la nueva política de inmigración pareció haberse preocupado por la falta de viviendas, y la mínima disponibilidad de servicios de salud, educación, transporte y todos aquellos servicios básicos que estos inmigrantes iban a necesitar desesperadamente (Palma, 2019b).

\footnotetext{
${ }^{33}$ Sobre cómo lo hizo la República de Corea durante su proceso de industrialización, véase Chang (1993); para el caso de la provincia china de Taiwán, Wade (2003). Para un resumen, véase Palma (2019a, gráfico 22).
} 
De esta forma, un modelo de crecimiento basado en la abundancia de mano de obra barata y falta de crecimiento de la productividad (y la continua diversificación horizontal en lo productivo en el exterior) podía seguir adelante. Volviendo a Voltaire, la comodidad de los ricos también depende de un suministro abundante de los pobres en la esfera de la producción.

Fue precisamente este "más de lo mismo" lo que hizo que el modelo neoliberal fuera totalmente incapaz de actualizarse cuando sus motores de crecimiento existentes (la mera extracción de recursos naturales y los servicios baratos) se agotaron. El capitalismo "placentero" -y su orden de acceso limitado- se había vuelto autodestructivo. La oligarquía solo puede culparse a sí misma del hecho de que la estrategia 3 se volviese contradictoria con respecto a sus propios intereses de largo plazo.

Esta inercia de insistir en el "más de lo mismo" -esto es, esta resistencia del statu quo a la alteración de su estado de reposo-, esta calma de la inacción, nos recuerda las novelas de Conrad en las cuales, como en tantas historias del mar, el enemigo principal de la creatividad es la estasis. De hecho, es lo más mortífero (Segal, 1997).

Finalmente, y a diferencia de lo que indican las encuestas de hogares (gráfico 7 y Casen, 2020), nuevos datos tributarios sugieren que la estrategia 3 tuvo mucho más éxito en términos distributivos para las personas con mayores ingresos de lo que se cree hasta el momento, lo que plantea más dudas sobre la supuesta disminución de la desigualdad en Chile (véase el gráfico 9).

\section{Gráfico 9}

Chile: participación del 1\% más rico y del 10\% más rico en el ingreso antes de impuestos y el índice de Palma después de impuestos y transferencias, 2000-2019

(En porcentajes y cocientes)

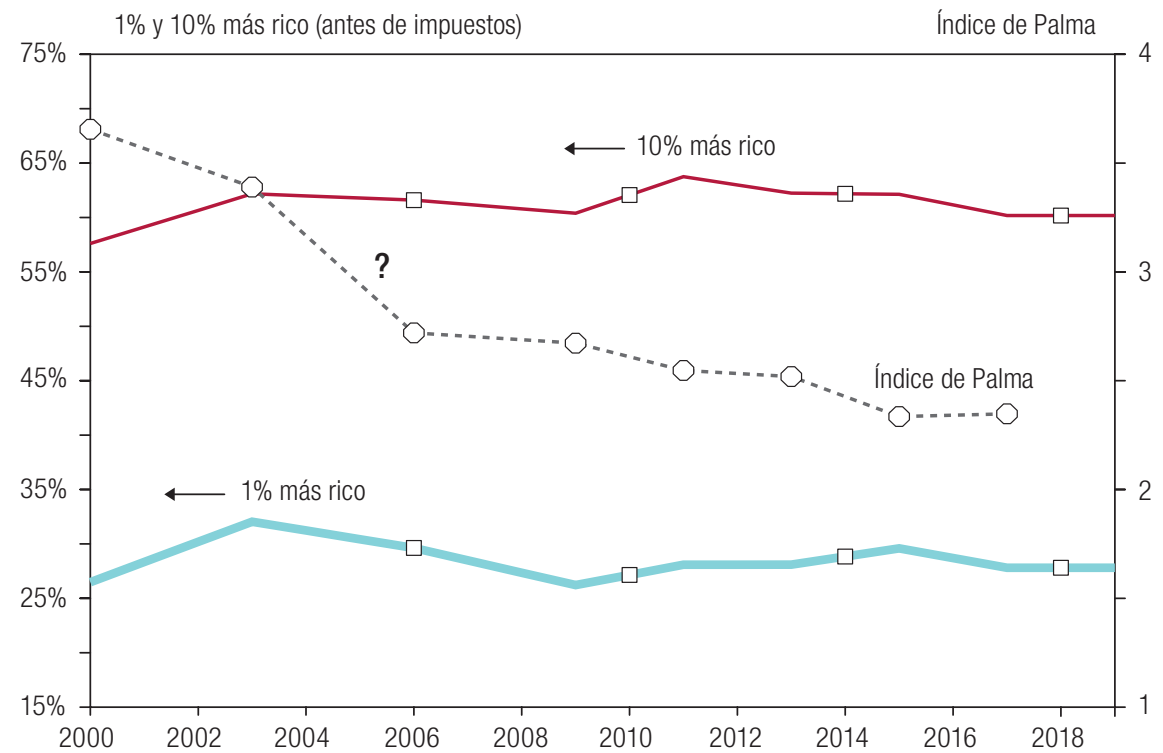

Fuente: World Inequality Lab, World Inequality Database, 2020 [en línea] http://wid.world/, sobre la base de M. de Rosa, I. Flores y M. Morgan, "Inequality in Latin America revisited: insights from distributional national accounts", Technical Note, $N^{\circ}$ 2020/02, 2020 (para el ingreso antes de impuestos); y J. G. Palma, "Behind the seven veils of inequality: what if it's all about the struggle within just one half of the population over just one half of the national income?", Development and Change, vol. 50, № 5, septiembre de 2019 (para el coeficiente de Palma).

Nota: Los círculos indican los años en que se realizó la principal encuesta de hogares (CASEN, 2020); los cuadrados indican períodos presidenciales.

Si la participación de los más ricos se mantuvo básicamente estable durante este período, una disminución del coeficiente de Palma de esta naturaleza (especialmente hacia el final del período de la presidencia de Ricardo Lagos; ver signo de interrogación en la figura) habría necesitado un aumento de 
la participación del 40\% más pobre de aproximadamente el doble del nivel informado en las encuestas de presupuesto familiar. Es difícil creer que en un país con un sistema impositivo tan bajo y regresivo, la supuesta disminución informada en dichas encuestas de la participación en los ingresos después de impuestos de quienes están en la parte superior se deba a otra cosa que no sea la creciente incapacidad de esas encuestas para reflejar los ingresos de los ricos en este mundo cada vez más financierizado (y convertido en un paraíso fiscal universal).

En resumen, a pesar de que la estrategia 3 se convirtió en un fracaso abyecto en materia de productividad en el mediano plazo, fue un gran éxito para los ricos en términos distributivos, hasta que el estallido del descontento popular le puso fin repentinamente con una demostración de poder social que no se había visto en Chile desde la derrota de Pinochet en su plebiscito de 1988. El poder de los jóvenes (enfurecidos por un futuro sin esperanzas que se les ofrecía con esta estrategia) y el movimiento feminista (que dijo basta al abuso y discriminación de género sufrido a todos los niveles) ${ }^{34}$ -no ayudado por la violencia de un gran grupo de jóvenes que se han automarginado, aquellos que ni estudia, ni trabaja o ni busca trabajo- rompieron el hechizo ideológico neoliberal: el emperador (el que predicaba que "no hay alternativas") iba desnudo.

\section{Estrategia 4. De la estrategia distributiva "preferida" de la élite (la 3) a una búsqueda (un tanto desesperada) de paz social a través de un fuerte incremento de la protección social (a la "nueva socialdemocracia" europea)}

Aunque este nuevo cambio distributivo involucra muchos aspectos, no cabe duda de que el más importante es que la realidad económica transparentó cómo en la estrategia 3 la supremacía de las rentas fáciles indujo una falta de dinamismo productivo. Además, las nuevas tecnologías de comunicación social han contribuido a mejorar la cohesión social entre la mayoría y empoderado su "voz" (en el sentido de Hirschman ya citado). Antes, la mayor capacidad de acción colectiva de la élite gracias a su cohesión interna ayudaba a su ventaja en los juegos del gallina; pero ahora, las nuevas tecnologías de la comunicación cambiaron este escenario. Como demuestra el estallido social en Chile, estas nuevas tecnologías han llevado a un punto de inflexión en esta materia.

El estallido social en octubre de 2019 fue seguido rápidamente por la aparición de la pandemia, la cual produjo una distracción temporal del descontento social. Sin embargo, como la pobreza y el desempleo crecieron rápidamente, mientras el gobierno de centro-derecha le costaba responder, esta distracción no duró. Por su parte, el hecho de que casi todas las grandes fortunas siguieron creciendo como en las mejores épocas (ayudadas por la "manía perpetua" del casino financiero (Palma, 2020b)), se transformó en un insulto a la mayoría de la población. Cuando finalmente llegó el plebiscito de octubre de 2020 sobre si cambiar la Constitución de Pinochet, obtuvo un 80\% de apoyo.

Desde la perspectiva de este trabajo, una de las repercusiones clave de la pandemia fue que expuso todo tipo de desigualdades. Por ejemplo, mientras que en un barrio de clase media (Ñuñoa) las dos razones principales para solicitar un permiso para salir de casa durante el confinamiento fueron ir al supermercado y a pasear sus perros (de pedigrî), en un barrio de clase obrera (La Pintana) ellas eran asistir a entierros y visitar a familiares en instituciones penitenciarias. Además, la baja cobertura de Internet (solo un 13\%) obligó a las personas de este barrio a salir de casa incluso si hubiesen podido trabajar o estudiar desde ahí.

${ }^{34}$ Su eslogan "el Estado opresor es un macho violador" lo decía todo (https://www.youtube.com/watch?v=tB1cWh27rml). 
La combinación de la explosión del malestar y la pandemia generó una gran ansiedad -y, en muchos casos, directamente pánico- entre la élite de que Chile se volvería políticamente ingobernable tan pronto como se volviera a algo parecido a la normalidad. Para un respetado analista de derecha, por ejemplo,

"El mayor temor no es el coronavirus, que pasará aunque se cobrará muchas vidas [...] tampoco es la inminente debacle económica, que finalmente también se recuperará [...] su mayor temor [...] es ese grupo social inmanejable que se está marginando, saliéndose de la sociedad y de las normas de vida en común"35.

Ante estas incertidumbres y desafíos, algunos políticos y líderes empresariales vieron en el discurso de la "nueva socialdemocracia" europea una salida a su impase estratégico, con la esperanza de que podría garantizar un mínimo de protección social y paz (estrategia 4).

Por ejemplo, los presidentes de las principales asociaciones empresariales, a diferencia de todo lo que habían predicado durante generaciones (especialmente desde las reformas neoliberales), comenzaron a idealizar un modelo estilo nueva socialdemocracia europeo ${ }^{36}$. Incluso algunos intelectuales de esa orientación política comenzaron a publicar manifiestos socialdemócratas para ayudar a que futuros gobiernos no pasaran de un estallido social a otro (Waissbluth, 2020). Un ex Ministro de Hacienda del actual gobierno de derecha, y ahora candidato presidencial, expresó una opinión similar. Por su parte, otro candidato de la derecha a las próximas elecciones presidenciales (uno de los "Chicago Boys" y un exfavorito de Pinochet) también, por primera vez, se definió a sí mismo como socialdemócrata y hasta dijo que estaba a favor de un Estado más fuerte, capaz de garantizar los derechos sociales (El Mercurio, 2020).

Como cabía esperar, algunos de la "nueva" izquierda enfurecieron, alegando que se trataba de ¡una grave vulneración de sus derechos de propiedad intelectual!

Curiosamente, fueron precisamente las incoherencias entre las agendas económica y social de la nueva socialdemocracia europea (véase Palma, 2019a) lo que hizo esta estrategia 4 tan atractiva para quienes buscaban la inercia del statu quo, pero con paz social (véase el anexo A2). Mientras que la agenda económica buscaría ofrecer más de lo mismo, la nueva agenda social podría dar un nuevo aliento a su modelo neoliberal, ahora frágil. Además, la élite tiene un as en la manga: en este mundo financierizado, en lugar de tener que pagar la protección social adicional con nuevos impuestos, siempre se puede recurrir al endeudamiento adicional del sector público. Por lo tanto, para la comunidad empresarial cambiar a la estrategia 4 podría ser doblemente beneficioso: podría relegitimizar el modelo rentista neoliberal al hacerlo un poco más civilizado, y los bonos del Estado (en lugar de impuestos) podrían financiar la tan necesaria paz social combatiendo la pobreza y dando un grado mínimo de equidad. ¿Cómo no se les había ocurrido antes?

Básicamente sería una forma de cuadrar el círculo: los agentes poderosos podrían continuar manipulando el mercado de productos y los mercados financieros como les placiera (incluso seguir extendiendo el mercado hasta esferas de la vida social donde hasta ahora había sido inaceptable, e incluso inconcebible, y que de paso ya han generado algunas de las actividades más ineficientes de la economía), y un gasto deficitario del sector público podría fomentar la inmunidad de rebaño necesaria para la paz social.

Desde esta perspectiva, la nueva estrategia tiene mucho sentido para la élite, y el número cada vez menor de personas dentro del grupo que todavía la rechazan lo hacen más bien impulsados por el poder autodestructivo del fundamentalismo. El elemento más atractivo para la derecha más ilustrada es que esta nueva alternativa, a la vez de ofrecer un mínimo de paz social y cierta igualdad, le permite

\footnotetext{
35 Véase [en línea] https://www.latercera.com/opinion/noticia/el-miedo/SS57SUH65JGWXEE4VDXJD5N2W4/.

${ }^{36}$ Véase, por ejemplo, [en línea] https://interferencia.cl/articulos/entrevista-juan-sutil-desde-el-punto-de-vista-social-probablementechile-tiene-que-avanzar.
} 
mantener los aspectos buchanianos de su modelo, los que la Constitución de Pinochet y sus "leyes de amarre" (acordadas con la centroizquierda durante la transición a la democracia (véase el anexo A1)) son ejemplos paradigmáticos. Entre otros, el proyecto actualmente en el Senado para apoyar el ya mencionado tratado "TPP-11" es un ejemplo paradigmático (Palma, 2021).

Para Buchanan (1993), quienes realmente necesitaban protección social eran las grandes empresas, y sus derechos de propiedad solo se podían proteger imponiendo garantías constitucionales. Buchanan tenía una visión más bien paranoica de la sociedad; para él, existían un conflicto eterno entre los "creadores" (empresarios) y los "saqueadores" (todos los demás), quienes constantemente asediaban a los primeros. En su trabajo advierte repetidamente del peligro de los parásitos y depredadores asechando innovadores, por lo que había que darles protección social limitando constitucionalmente al cambio.

Como en el resto de América Latina, en Chile esta influencia buchaniana también ha permeado la ideología de la "nueva" izquierda. Desde la transición a la democracia no ha ahorrado esfuerzos para disculparse por su pasado "predatorio" (por ejemplo, por haber respaldado reformas agrarias y nacionalizaciones de los recursos naturales, entre otros). Lo mismo ha ocurrido en Chile con el Partido Demócrata Cristiano. En los años sesenta su primer Presidente, Eduardo Frei Montalva, tuvo una agenda económica muy en consonancia con su agenda social: las reformas agrarias y la nacionalización parcial de la gran minería del cobre fueron de la mano de políticas de protección social y empoderamiento social (la famosa política de "promoción popular"). Sin embargo, en los años noventa, durante la presidencia de su hijo, Eduardo Frei Ruiz-Tagle, si bien la agenda social fue similar a la de su padre (aunque se la llevó a cabo con un número muy superior de consultorías), la agenda económica intentó construir un futuro opuesto al del pasado. Y como esas agendas iban en direcciones opuestas, se obstruyeron entre sí.

Además, el apoyo de la mayor parte del centroizquierda a estas barreras constitucionales para defender los derechos de propiedad de los "creadores" se da a pesar de la manera más bien poco creativa en que muchos de estos supuestos innovadores adquirieron sus activos -en tantos casos, saqueando empresas públicas y recursos naturales durante las reformas neoliberales plagadas de corrupción, con el acceso a verdaderas piñatas restringidas a los cortesanos del régimen y familiares del dictador_ 37 .

La interrogante, por supuesto, es si en América Latina esta nueva estrategia 4 logrará su objetivo de ser un mecanismo eficaz y sostenible para compatibilizar la agenda económica neoliberal tradicional con una agenda social (socialdemócrata) más civilizada como lo ha sido hasta ahora en Europa Occidental. Asimetrías de esta naturaleza son, sin duda, más frágiles en la periferia que en el centro.

Además, es posible que la estrategia 4 haya llegado demasiado tarde a América Latina, como fue el caso de las concesiones aristocráticas en la Francia de finales del siglo XVIII. Las oligarquías latinoamericanas ciertamente necesitarán sus mejores "juegos de cintura" -y la acción colectiva apropiada- para que esta nueva estrategia funcione. En esta materia, todo está por verse.

\section{Conclusiones}

Este artículo intenta responder a la pregunta del por qué los ricos tienen tanta facilidad para seguir siendo ricos al margen de lo que quiera el resto de la sociedad. Desde un punto de vista analítico hace un contraste entre la visión neoclásica, que enfatiza que la enorme desigualdad en América Latina es el resultado de la interacción natural de una serie de "fundamentos" relativamente exógenos y de naturaleza fundamentalmente económica, a una ricardiana, donde lo esencial es la articulación de un conflicto distributivo antagónico entre rentistas, capitalistas, burócratas y trabajadores. Esta refleja tanto las interacciones particulares entre las estructuras del poder y las fallas del mercado, como la

37 Véanse, por ejemplo, Mönckeberg (2015), Gárate Chateau (2012) y Palma (2013). 
capacidad de una sociedad para optar entre alternativas en un mundo de equilibrios múltiples. Y en donde la historia, la política y las instituciones importan tanto o más que los "fundamentos" económicos.

Dentro de esta perspectiva, el desafío analítico se centra en el cómo conseguimos descorrer los velos que esconden estas interacciones y distorsionan nuestra visión de la naturaleza autoconstruida de la desigualdad. Por tanto, en lugar de pensar (como en la mayoría de las narrativas neoclásicas) en los posibles efectos concretos que factores conocidos pueden tener sobre la desigualdad (por ejemplo, la tecnología, la movilidad social y la educación, entre otros), sería más esclarecedor tratar de entender las expresiones concretas que estos factores pueden adquirir en situaciones reales de desigualdad, como el de Chile. De hecho, algunas de las piezas del rompecabezas distributivo bien podrían ser las mismas en diferentes situaciones, pero la forma en que encajan podría variar (a veces, considerablemente).

Como argumenté primero en Palma (1978) y luego desarrollé en (2016b), el desafío analítico en temas como la desigualdad no es el de formular teorías "mecánico-formales" que supuestamente lo expliquen todo genéricamente, sino desarrollar metodologías para el análisis de situaciones concretas de fenómenos como la desigualdad (el objetivo principal de este trabajo).

En lo fundamental, si bien está claro que la economía capitalista tiende hacia un mayor nivel de desigualdad -y no tanto por cuestiones neoclásicas como el " $r>g$ " de Piketty ${ }^{38}$, sino porque la élite, con su poder material, hegemonía ideológica, flexibilidad estratégica y su cohesión interna, tiene la opción de seguir varios caminos para conseguir las mismas ventajas en el conflicto distributivo-; si bien también está claro que estamos inmersos en un proceso de creciente internacionalización y financierización, que las sociedades están divididas en grupos fundamentalmente antagónicos y que lo particular está, en cierta medida, condicionado por lo general, entonces la pregunta que debemos hacernos es por qué a partir de estas premisas no hemos ido más allá de una caracterización parcial -y, por lo tanto, abstracta - del fenómeno de la desigualdad. Aún queda el paso siguiente, el aterrizar el análisis a la especificidad de situaciones concretas de desigualdad.

Una lección clave de la compleja experiencia chilena en lo distributivo es que transparenta el problema fundamental del pensamiento neoclásico: nunca ha podido romper con su pecado original, el pensar la distribución del ingreso como el resultado natural (y bastante mecánico) del valor relativo de productividad marginales (Solow, 1956). Además, en este análisis se asume como "dados" la tecnología, las preferencias y la dotación de factores; y la historia, las instituciones y la política son extras opcionales.

Por ejemplo, aunque Chile tiene el mismo PIB per cápita y el mismo salario medio que Croacia (Banco Mundial, 2020), su mediana salarial es solo la mitad de la de Croacia (Durán y Kremerman, 2020). Evidentemente esto no se debe a que algunos "fundamentos" predeterminados hayan obligado a Chile a tener tal desigualdad salarial. Aquí el tema fundamental es uno de opciones entre alternativas reales para hacer las cosas. Ya basta el seguir pensando que somos espectadores inocentes a merced de fuerzas distributivas exógenas ${ }^{39}$. Y esa elección, por supuesto, no se da en el vacío, sino que se toma dentro de un rango asociado a la interacción entre nuestra historia, política e instituciones con algunos de esos fundamentos y fallas y distorsiones de mercado. Como ya se sugirió, lo crítico en esto es la agencia, pero para que una agencia pueda tener éxito, necesita comprender la estructura.

Evidentemente ninguna fuerza predeterminada nos ha obligado en Chile (con su nivel de ingreso medio alto) a tener una mediana salarial neta que no es capaz de sacar del umbral de la pobreza a una familia de cuatro personas. Todo esto en un país al que le gusta pensar que está ad portas de convertirse en un país "desarrollado": un buen ejemplo de una ilusión que raya en lo delirante.

\footnotetext{
38 Donde "r" es el retorno de las inversiones y " $g$ " la tasa de crecimiento de una economía.

39 Para ver una crítica de los modelos distributivos neoclásicos y de su econometría -especialmente sobre el uso del índice de Gini como variable dependiente, que conduce a errores de especificación y a la endogeneidad-, véase Palma (2019a).
} 
En otras palabras, nada revela más claramente quiénes de verdad somos en Chile como sociedad que la desigualdad que colectivamente elegimos construir. En resumidas cuentas, como en la mayor parte del mundo, en Chile nos merecemos la desigualdad que tenemos (Palma, 2016a). ¡Se trata del acto más autodefinitorio que pueda haber!

Por ejemplo, Chile gasta el doble que Croacia en educación, y un 50\% más en salud, en términos de porcentaje del gasto público, y su matriculación en educación superior es un tercio más alta; tiene una calificación mucho más alta en Moody's (A1 y no Ba1), Standard \& Poor's (A+ y no BBB-) y Fitch Ratings (A-y no BBB-); tiene un nivel de corrupción mucho menor en los rankings tradicionales; su Estado es menos "frágil"; su posición de la balanza de pagos es mucho mejor, y así sucesivamente, pero su coeficiente de Palma es 2,8 (y el índice de Gini, 48), mientras que en Croacia el coeficiente de Palma es solo 1,1 (y el índice de Gini, 31) (Banco Mundial, 2020).

Quizás el hecho de que su índice de homicidios por 100.000 habitantes (aunque muy bajo con respecto al promedio latinoamericano) sea cuatro veces mayor al de Croacia es un indicador mucho más revelador en cuanto a la forma como en Chile se autoconstruye la desigualdad -y del modo en que se articulan los conflictos en general- que lo que las agencias de calificación nos puedan decir de ambos países.

Otra lección crucial de la experiencia chilena es que en países con altos niveles de desigualdad creados artificialmente, la mayoría de las vías disponibles para que la élite salga ganando están vinculadas con ineficiencia en lo económico. Se distorsionan mercados para generar el exceso de desigualdad, y luego (salvo situaciones muy específicas, como el Chile de los noventa) dicho "exceso" ni siquiera vuelve a la economía en forma productiva (inversión).

Principalmente por eso (aunque no únicamente), estas vías o estrategias se convierten en juegos perdedores si se juegan indefinidamente. Por lo tanto, el secreto de la élite es tener la flexibilidad y cohesión interna suficientes como para jugar una secuencia de estrategias perdedoras que ganen; es decir, la paradoja de Parrondo. Quizás la mayor contribución de Chile al análisis de la desigualdad es que ambos fenómenos -la relación entre la desigualdad autoconstruida y la ineficiencia económica, y la paradoja- han tenido lugar de una forma bastante transparente.

En cuanto a los países de la OCDE, ninguna fuerza exógena los obligó a "bananizar" su desigualdad mercado (véase el gráfico A2.1); la cuestión fundamental es asumir la responsabilidad de nuestras elecciones distributivas. La desigualdad mercado de Alemania (y casi todos en la OCDE de altos ingresos) no solo está cerrando la brecha "al revés" (reverse catching-up) con respecto al trópico, sino que incluso ya supera a casi todas las latinoamericanas. Claramente fue su elección: una que autodefine su actual configuración política.

Así pues, la vida ya no es tan sencilla en los países de la OCDE de altos ingresos, pues además de una familia hay una oligarquía que mantener. Es tentador decir ;"bienvenidos al tercer mundo"!

A su vez, la situación distributiva en América Latina, a lo Sur de Estados Unidos, hasta el momento ha demostrado ser algo que se asemeja a un "proceso estacionario" pues sus elaboradas maniobras defensivas frente a eventos desequilibrantes han estado a la altura de las circunstancias. Por lo tanto, las perturbaciones políticas -como la crisis financiera de 1982, cuando el PIB de Chile cayó un 20\%, el desempleo subió al 30\% y la mitad de la población cayó debajo del umbral de la pobreza, o el impacto del retorno a la democracia- solo han tenido repercusiones de corta duración (la fuerza del impacto se ha disipado en poco tiempo).

Así pues, en esta situación estacionaria de gatopardismo, frente a eventos perturbadores se ha dejado que casi todo cambie para que todo lo que le importa a la élite se mantenga igual. La gran pregunta actual en Chile es si ahora va a pasar lo mismo con el estallido social de octubre de 2019, que ahora se mezcla con la pandemia y la nueva Constitución. ¿Volverá la oligarquía a salirse con la suya, o será esto un golpe que finalmente tenga un efecto más permanente en el proceso de acumulación y 
dominación? Es decir, ¿serán impactos que transformen todo en un proceso tipo "raíz unitaria", donde la fuerza de impactos de dicha naturaleza no decaiga con el tiempo?

Lo que está en juego es si la estrategia 4, y la nueva agenda social de la élite, van a ser capaces de repetir el truco gatopardista. Eso es lo que "sabemos que no sabemos" (known unknown) del Chile actual -y del de otras partes de la región-.

Otro misterio es cómo es posible que esta oligarquía sea tan flexible para enfrentar impactos distributivos, y reformular su estrategia para revertirlos, pero sea tan rígida en cuestiones económicas. Ciertamente, todavía sigue atascada en un modelo neoliberal de los años setenta claramente obsoleto, basado en la versión más primitiva del Consenso de Washington. Si en un ámbito son los maestros de la "articulación política", en el otro han demostrado la maniobrabilidad de un petrolero.

El desafío económico que enfrentan los países de la región es titánico: como se ha explicado anteriormente, el problema fundamental de la agenda económica actual de América Latina es que es muy difícil remodelar los componentes de la estructura de un sistema económico con tan poca entropía; esto es, si se impone como condición que los fundamentos del statu quo no se pueden alterar, hay muy pocas formas de avanzar en el tiempo. Si los que están arriba quieren seguir acaparando la tajada del león por recolectar la fruta que está al alcance de la mano, tienen que gastar mucha energía tratando de "parar el tiempo". Por tanto, queda poca para avanzar con él hacia estructuras más flexibles -donde se pueda "desordenar" estas rigideces, buscando rearreglar los componentes en formas más imaginativas (y eficientes)-.

Y hablando de "desordenar" rigideces para rearreglar componentes en formas más imaginativas, la nueva socialdemocracia europea también tiene un gran desafío de esta naturaleza con su sistema de protección social.

Además, esta vez la ayuda de la nueva izquierda no es tan útil como lo fue con las estrategias 2 y 3 , ya que este grupo ha perdido la mayor parte de su influencia política. Ya decíamos que para Adorno (1951) esto no es una cuestión menor, ya que la dominación es más efectiva cuando la oligarquía "puede delegar la violencia en la que se basa en los dominados".

Como se analizó en Palma (2020a), América Latina está ahora atrapada en lo que denomino un "momento gramsciano", cuando lo viejo se desvanece, pero lo nuevo no logra nacer; es decir, cuando la élite y su "modelo" pierden su legitimidad, pero los discursos alternativos aún no han conseguido generar suficiente credibilidad. En este interregno, como nos advierte Gramsci (2000) -y como muchos viven de primera mano en América Latina, especialmente en el Brasil- es casi inevitable que aparezca una "gran variedad de síntomas perjudiciales". Parte del problema es que la inercia neoliberal de la región también ha apagado su imaginación social (Palma, 2016b).

En resumen, si la plasticidad de la élite latinoamericana en cuestiones relativas a su estrategia distributiva se hubiese replicado en el ámbito económico, su economía (y otros ámbitos) se estarían hundiendo cada vez más en las arenas movedizas de la inercia (mi definición de la "trampa del ingreso medio"), del que Chile es un caso paradigmático (Palma, 2019b).

La oposición freudiana entre el instinto de supervivencia y el impulso autodestructivo parece manifestarse de manera bastante transparente en los temas analizados en este artículo, en especial, en el conflicto recurrente entre la gran "capacidad de persistir" de la élite latinoamericana y su impulso rentista autodestructivo. 


\section{Bibliografía}

Acemoglu, D. y J. A. Robinson (2006), Economic Origins of Dictatorship and Democracy, Cambridge, Cambridge University Press.

Adorno, T. (1951), Minima Moralia: Reflections from Damaged Life, New Left Books.

Arantes, P. (2007), Extinção, São Paulo, Boitempo.

Atkinson, A. (2015), Inequality: What Can Be Done?, Cambridge, Harvard University Press.

Atria, J. y otros (2018), "Top incomes in Chile: a historical perspective of income inequality (1964-2015)", Working Paper Series, № 2018/11, World Inequality Lab.

Avdjiev, S., P. McGuire y G. von Peter (2020), "International dimensions of EME corporate debt”, BIS Quarterly Review, junio.

Banco Central de Chile (2020), "Inversión Extranjera Directa (IED)" [en línea] https://si3.bcentral.cl/estadisticas/ Principal1/enlaces/IED/IED.html.

Banco Mundial (2020), World Development Indicators [en línea] https://datatopics.worldbank.org/worlddevelopment-indicators/. (2016), Poverty and Shared Prosperity 2016: Taking on Inequality, Washington, D.C.

Benjamin, W. (1968), Illuminations: Essays and Reflections, San Diego, Harcourt Brace Jovanovich.

Blakeslee, S. (2000), "Paradox in game theory: losing strategy that wins", The New York Times, 25 enero [en línea] https://www.nytimes.com/2000/01/25/science/paradox-in-game-theory-losing-strategy-thatwins.html.

Boix, C. (2003), Democracy and Redistribution, Cambridge, Cambridge University Press.

Bourguignon, F. (2017), La globalización de la desigualdad, Ciudad de México, Fondo de Cultura Económica.

Britton, R. (1998), Belief and Imagination: Explorations in Psychoanalysis, Londres, Routledge.

Buchanan, J. (1993), "How can constitutions be designed so that politicians who seek to serve 'public interest' can survive and prosper?", Constitutional Political Economy, vol. 4, diciembre.

CEPAL (Comisión Económica para América Latina y el Caribe) (2016), "Evasión fiscal en América Latina llega a 340.000 millones de dólares y representa 6,7\% del PIB regional", 1 de septiembre [en línea] https:// www.cepal.org/es/noticias/evasion-fiscal-america-latina-llega-340000-millones-dolares-representa-67pib-regional.

Chang, H. J. (1993), "The political economy of industrial policy in Korea”, Cambridge Journal of Economics, vol. $17, \mathrm{~N}^{\circ} 2$, junio.

CMD (Centro de Microdatos) (2019), "Encuesta de Ocupación y Desocupación”, Universidad de Chile [en línea] http://documentos.microdatos.cl/Encuestas/Ocupacion/OcupacionDesocupacion?C=T1.

De Rosa, M., I. Flores y M. Morgan (2020), "Inequality in Latin America revisited: insights from distributional national accounts", Technical Note, № 2020/02, World Inequality Lab.

Díaz Alejandro, C. F. (1983), "Some aspects of the 1982-83 Brazilian payments crisis", Brookings Paper on Economic Activity, $\mathrm{N}^{\circ} 2$.

Di John, J. (2006), "The political economy of taxation and tax reform in developing countries", Research Paper, NN 2006/74, Helsinki, World Institute for Development Economics Research (UNU-WIDER).

Durán, G. y M. Kremerman (2020), Los verdaderos sueldos de Chile: panorama actual del valor de la fuerza de trabajo usando la Encuesta Suplementaria de Ingresos ESI (2019), Santiago, Fundación Sol.

El Mercurio (2020), “¿Qué significa ser socialdemócrata?: la pregunta que surge tras la sorpresiva definición de Joaquín Lavín”, 24 de agosto [en línea] https:/www.emol.com/noticias/Nacional/2020/08/24/995890/ ser-socialdemocrata-definicion-Lavin.html.

Engel, E., A. Galetovic y C. Raddatz (1999), "Taxes and income distribution in Chile: some unpleasant redistributive arithmetic", Journal of Development Economics, vol. 59, № 1, junio.

Financial Times (2020a), "Pandemic makes world's billionaires - and their advisers - richer", 23 de octubre [en línea] https://www.ft.com/content/ab30d301-351b-4387-b212-12fed904324b.

_ (2020b), "Eurozone budget deficits rise almost tenfold to counter pandemic", 18 de octubre [en línea] https://www.ft.com/content/5579361f-5aac-4cd3-9e93-190fffdc0baf.

Fishlow, A. (1972), "Brazilian size distribution of income", American Economic Review, vol. 62, № 2, mayo.

Foucault, M. (2009), Nacimiento de la biopolítica: curso del Collège de France (1978-1979), Madrid, Ediciones Akal.

Frangie, S. (2008), "The 'political economy of consensus' in post-civil war Lebanon, 1993-2005”, tesis de doctorado, Universidad de Cambridge. 
Galbraith, J. (2016), Inequality: What Everyone Needs to Know, Oxford, Oxford University Press.

Gárate Chateau, M. (2012), La revolución capitalista de Chile (1973-2003), Santiago, Ediciones Universidad Alberto Hurtado.

Gramsci, A. (2000), Cuadernos de la cárcel, Ciudad de México, Ediciones Era/Benemérita Universidad Autónoma de Puebla.

Harcourt, G. (2015), "Review article: Thomas Piketty", Capital in the Twenty-First Century', The Economic and Labour Relations Review, vol. 26, N2 2, mayo.

Heisenberg, W. (1971), Physics and Beyond: Encounters and Conversations, Crows Nest, Allen \& Unwin.

Herman, E. S. y N. Chomsky (1988), Manufacturing Consent: The Political Economy of the Mass Media, Nueva York, Pantheon Books.

Hirschman, A. (1970), Exit, Voice, and Loyalty: Responses to Decline in Firms, Organizations, and States, Cambridge, Harvard University Press.

Kaldor, N. (1955), "Alternative theories of distribution", The Review of Economic Studies, vol. 23, № 2, enero.

Kant, I. (1998), Critica de la razón pura, Cambridge, Cambridge University Press.

Key, E., M. Klosek y D. Abbott (2006), "On Parrondo's paradox: how to construct unfair games by composing fair games", The ANZIAM Journal, vol. 47, № 4, abril.

Keynes, J. M. (1936), The General Theory of Employment, Interest and Money, Nueva York, Harcourt, Brace and Howe.

- (1920), The Economic Consequences of the Peace, Nueva York, Harcourt, Brace and Howe.

Khan, M. (2018), "Political settlements and the analysis of institutions", African Affairs, vol. 117, № 469, octubre. (2005), "The capitalist transformation", The Origins of Development Economics: How Schools of Economic Thought Have Addressed Development, K. Jomo y E. Reinert (eds.), Nueva Delhi, Zed.

Krugman, P. (2011), "Mr Keynes and the moderns", 21 de junio [en línea] https://voxeu.org/article/mr-keynesand-moderns.

(2005), "The debt-peonage society", The New York Times, 8 de marzo [en línea] www.nytimes. com/2005/03/08/opinion/the-debtpeonage-society.html.

(1994), The Age of Diminished Expectations: U.S. Economic Policy in the 1990s, Cambridge, MIT Press.

Laclau, E. y C. Mouffe (2011), Hegemony and Socialist Strategy: Towards a Radical Democratic Politics, Londres, Verso.

Lamarca, F. (2009), Las prisas pasan, las cagadas quedan, Santiago, La Tercera Ediciones.

Lawson, T. (2003), Reorienting Economics, Abingdon, Routledge.

Levi, P. (1986), "Primo Levi's heartbreaking, heroic answers to the most common questions he was asked about 'Survival in Auschwitz'", The New Republic, 17 de febrero [en línea] https://newrepublic.com/ article/119959/interview-primo-levi-survival-auschwitz.

Libreria Editrice Vaticana (2015), "Discurso del Santo Padre Francisco a los representantes de la Confederación Italiana de Cooperativas", 28 de febrero [en línea] http://www.vatican.va/content/francesco/es/speeches/2015/ february/documents/papa-francesco_20150228_confcooperative.html.

Lieberman, E. (2003), Race and Regionalism in the Politics of Taxation in Brazil and South Africa, Cambridge, Cambridge University Press.

López, R. y S. Miller (2008), "Chile: the unbearable burden of inequality", World Development, vol. 36, $\mathrm{N}^{\circ} 12$, diciembre.

Mazzucato, M. (2018), The Value of Everything: Making and Taking in the Global Economy, Londres, Allen Lane. (2013), The Entrepreneurial State: Debunking Public vs. Private Sector Myths, Londres, Anthem Press.

Milanovic, B. (2019), Capitalism, Alone: The Future of the System That Rules the World, Cambridge, Harvard University Press.

(2016), Global Inequality: A New Approach for the Age of Globalization, Cambridge, Harvard University Press.

Ministerio de Desarrollo Social y Familia (2020), "Encuesta Casen" Observatorio Social [en línea] http:// observatorio.ministeriodesarrollosocial.gob.cl/encuesta-casen.

Mönckeberg, M. O. (2015), El saqueo de los grupos económicos al Estado chileno, Santiago, Debolsillo.

North, D. y otros (2007), "Limited access orders in the developing world: a new approach to the problems of development", Policy Research Working Paper, № 4359, Washington, D.C., Banco Mundial.

Northrop, F. S. (1958), "Introduction", Physics and Philosophy: The Revolution in Modern Science, W. Heisenberg, Harper Brothers.

Ocampo, J. A. (ed.) (2019), International Policy Rules and Inequality: Implications for Global Economic Governance, Nueva York, Columbia University Press. 
OCDE (Organización de Cooperación y Desarrollo Económicos) (2020a), OECD.Stat [base de datos en línea] https://stats.oecd.org/.

(2020b), "Revenue statistics in Latin America and the Caribbean 2020 - Chile" [en línea] http://www.oecd. org/tax/tax-policy/revenue-statistics-latin-america-and-caribbean-chile.pdf.

Oliveira, F. de (2003), "The duckbilled platypus", New Left Review, vol. 24, noviembre-diciembre.

Palma, J. G. (2021), "Todo lo que siempre quiso saber sobre el TPP-11 (pero nunca se atrevió a preguntar)", 26 de enero [en línea] https://www.ciperchile.cl/2021/01/26/todo-lo-que-siempre-quiso-saber-sobre-eltpp-11-pero-nunca-se-atrevio-a-preguntar/.

(2020a), "América Latina en su 'momento gramsciano': las limitaciones de una salida tipo 'nueva socialdemocracia europea' a este impasse”, El Trimestre Económico, vol. 87, № 348, octubre-diciembre [en línea] https://www.eltrimestreeconomico.com.mx/index.php/te/article/view/1146.

(2020b), "Finance as perpetual orgy: how the 'new alchemists' twisted Kindleberger's cycle of 'manias, panics and crashes' into 'manias, panics and renewed manias'”, Cambridge Journal of Economics, en prensa [en línea] http://www.econ.cam.ac.uk/research-files/repec/cam/pdf/cwpe2094.pdf.

(2020c), "What went wrong with European social democracy: on building a debilitating capitalism, where even the welfare State subsidises greater market inequality", Amartya Sen Lecture, 2020 Human Development and Capability Association (HDCA) Conference, Auckland, 30 de junio a 2 de julio [en línea] https://www.youtube.com/watch?v=wY9XFQA-McA\&feature=youtu.be.

_ (2019a), "Behind the seven veils of inequality: what if it's all about the struggle within just one half of the population over just one half of the national income?", Development and Change, vol. 50, № 5 , septiembre [en línea] https://onlinelibrary.wiley.com/doi/pdf/10.1111/dech.12505.

(2019b), "The Chilean economy since the return to democracy in 1990: on how to get an emerging economy growing, and then sink slowly into the quicksand of a 'middle-income trap'", Cambridge Working Papers in Economics, № 1991, Universidad de Cambridge [en línea] http://www.econ.cam.ac.uk/research-files/ repec/cam/pdf/cwpe1991.pdf.

(2018), “El TPP-11, el gobierno saliente y la 'utopía-invertida'”, Centro de Investigación Periodística (CIPER), 9 de marzo [en línea] https://www.ciperchile.cl/2018/03/09/el-tpp-11-el-gobierno-saliente-yla-utopia-invertida/.

(2016a), "Do nations just get the inequality they deserve? The 'Palma ratio' re-examined", Inequality and Growth: Patterns and Policy, vol. II, K. Basu y J. Stiglitz (eds.), Nueva York, Palgrave Macmillan [en línea] http://www.econ.cam.ac.uk/research/repec/cam/pdf/cwpe1627.pdf.

_ (2016b), "The 'dependency school' and its aftermath: why Latin America's critical thinking switched from one type of absolute certainties to another", Handbook of Alternative Theories of Economic Development, E. Reinert, J. Ghosh y R. Kattel (eds.), Cheltenham, Edward Elgar [en línea] http://www.econ.cam.ac.uk/ research-files/repec/cam/pdf/cwpe1416.pdf.

(2013), "¿Cuánto habrá que esperar para que los Chicago Boys \& Asociados respondan por el botín que algunos se llevaron?”, Centro de Investigación Periodística (CIPER), 12 de septiembre [en línea] https://www.ciperchile.cl/2013/09/12/\%C2\%BFcuanto-habra-que-esperar-para-que-los-chicago-boysasociados-respondan-por-el-botin-que-algunos-se-llevaron/.

(2011), "Homogeneous middles vs. heterogeneous tails, and the end of the 'inverted-U': it's all about the share of the rich", Development and Change, vol. 42, № 1, abril[en línea] http://www.econ.cam.ac.uk/ research-files/repec/cam/pdf/cwpe1111.pdf.

(1978), "Dependency: a formal theory of underdevelopment or a methodology for the analysis of concrete situations of underdevelopment?", World Development, vol. 6, № 7-8, julio-agosto.

Parrondo, J. M. (1996), "How to cheat a bad mathematician", Grupo de Mécanica Estadística de la Universidad Complutense de Madrid [en línea] http://seneca.fis.ucm.es/parr/GAMES/cheat.pdf.

Pérez, C. (2002), Technological Revolutions and Financial Capital: The Dynamics of Bubbles and Golden Ages, Cheltenham, Edward Elgar.

Piketty, T. (2020), Capital and Ideology, Cambridge, Harvard University Press. (2014), Capital in the Twenty-First Century, Cambridge, Harvard University Press.

Poulantzas, N. (1975), Political Power and Social Classes, Nueva York, New Left Books.

Ricardo, D. (1959), Principios de economía política y tributación, Ciudad de México, Fondo de Cultura Económica.

Rowthorn, R. (2014), "A note on Piketty's Capital in the Twenty-First Century", Cambridge Journal of Economics, vol. 38, № 5 , septiembre.

Russell, B. (1959), La guerra nuclear ante el sentido común, Madrid, Aguilar, S. A. de Ediciones. 
Sartre, J. P. (2004), Crítica de la razón dialéctica, Buenos Aires, Editorial Losada.

(1946), Las moscas (Les Mouches) y A puerta cerrada (Huis Clos), Londres, Hamish Hamilton.

Scheidel, W. (2017), The Great Leveler: Violence and the History of Inequality from the Stone Age to the Twenty-First Century, Princeton, Princeton University Press.

Segal, H. (1997), Psychoanalysis, Literature and War: Papers 1972-1995, Abingdon, Routledge.

Shakespeare (s/f), "Act 1. Scene Il", King Lear, The Literature Network [en línea] http://www.en línea-literature. com/shakespeare/kinglear/3/.

Smith, A. (1776), An Inquiry into the Nature and Causes of the Wealth of Nations, Edwin Cannan (ed.), Chicago, Chicago University Press.

Solow, R. M. (1956), "A contribution to the theory of economic growth,", The Quarterly Journal of Economics, vol. $70, \mathrm{~N}^{\circ} 1$, febrero.

Solt, F. (2020), "Measuring income inequality across countries and over time: the Standardized World Income Inequality Database", Social Science Quarterly, vol. 101, №3, SWIID version 9.0, octubre [en línea] https://fsolt.org/swiid/.

Stein, B. (2006), "In class warfare, guess which class is winning", The New York Times, 26 de noviembre [en línea] https://www.nytimes.com/2006/11/26/business/yourmoney/26every.html.

Stiglitz, J. E. (2012), The Price of Inequality: How Today's Divided Society Endangers Our Future, Nueva York, W. W. Norton.

Taylor, L. (2020), Macroeconomic Inequality from Reagan to Trump: Market Power, Wage Repression, Asset Price Inflation, and Industrial Decline, Studies in New Economic Thinking, Cambridge, Cambridge University Press.

- (2014), "The triumph of the rentier? Thomas Piketty vs. Luigi Pasinetti and John Maynard Keynes", International Journal of Political Economy, vol. 43, № 3.

The Conference Board (2020), "Total Economy Database: key findings" [en línea] https://www.conferenceboard.org/data/economydatabase/.

Wade, R. (2003), Governing the Market: Economic Theory and the Role of Government in East Asian Industrialization, Princeton, Princeton University Press.

Waissbluth, M. (2020), "Un manifiesto socialdemócrata", El Mostrador, 24 de julio [en línea] https://www. elmostrador.cl/destacado/2020/07/24/un-manifiesto-socialdemocrata.

Williamson, J. G. (2009), "Five centuries of Latin American inequality", NBER Working Paper, № 15305, Cambridge, Oficina Nacional de Investigaciones Económicas (NBER).

Wood, E. M. (2002), The Origin of Capitalism: A Longer View, Londres, Verso.

World Inequality Lab (2020), World Inequality Database [en línea] http://wid.world/.

Žižek, S. (2008), Violence, Nueva York, Picador. 


\section{Anexo A1}

\section{La "nueva" izquierda latinoamericana}

En forma muy breve (para un análisis detallado ver Palma (2016b)), la clave del éxito distributivo de la élite capitalista - aparte de su poder político de facto, su efectividad como grupo de presión, la capacidad de resolver sus propios problemas de acción colectiva y las astutas alianzas políticas con los estratos medios - ha sido su capacidad de crear consensos hegemónicos en torno a su ideología y praxis. La "nueva" izquierda es tan solo una de sus víctimas.

En parte por esto, en América Latina, como en muchas otras partes del mundo, la "nueva" izquierda se caracteriza por haber llegado a la conclusión (en forma un tanto apresurada) de que dentro de los parámetros actuales, tanto nacionales como internacionales, no sería posible construir alianzas que generen el apoyo necesarios para poder llevar a cabo agendas económicas progresistas.

La historia del Sur nos enseña que dichas agendas requieren un respaldo de amplias mayorías (todo indica que no bastan las simples mayorías) para poder hacer frente simultáneamente a todas las fuerzas internacionales y nacionales que se oponen a ellas compulsivamente. Esta base de apoyo es necesaria, por ejemplo, para que el Estado pueda disciplinar a la élite capitalista (y a veces a los trabajadores) a fin de poder construir una agenda económica que genere alta eficiencia y bajos niveles de desigualdad en el ámbito de la producción (como las que se encuentran en la República de Corea y la provincia china de Taiwán (véase el gráfico A2.2)).

En algunos casos -como los liderados por Nelson Mandela en Sudáfrica, Lula da Silva en el Brasil, y Patricio Aylwin y Ricardo Lagos en Chile-, las coaliciones de centro-izquierda en el Sur han tenido claras oportunidades para construir dichas alianzas y generar dichos apoyos. Sin embargo, y con demasiada facilidad, renunciaron a sus agendas económicas progresistas y abandonaron la economía como el eje del debate distributivo. En otras palabras, como la "nueva" izquierda creyó que no podría obtener el suficiente poder para implementar su propia agenda económica, trató de ganar poder para implementar la agenda de otros, pero de manera más eficiente y humana. Así, intentó conseguir el poder político para implementar lo que Francisco de Oliveira (2003) llamó una "hegemonía al revés" o lo que Paulo Arantes (2007) denominó una "utopía invertida"40.

En toda América Latina, pero especialmente en Chile y el Brasil (y también en Sudáfrica), la "nueva" izquierda utilizó el argumento de las "necesidades urgentes" para justificar el abandono de su agenda económica y redistributiva, para sustituirlas por políticas "prudentes" (esto es, aceptables a los grupos dominantes en el mercado).

En última instancia, según el concepto de Sartre (2004) de la mauvaise foi (mala fe), esto fue un ejercicio para convencer tanto a los demás como a sí mismos de que la transformación de la sociedad se había convertido en un riesgo inaceptable. Por lo tanto, un componente clave de su aparente pragmatismo fue nunca decir ni hacer nada que pudiera despertar a los fantasmas del pasado (Arantes, 2007).

Cuando se preguntó a Margaret Thatcher cuál era su mayor logro político, su respuesta no dejó lugar a dudas: transformar al Partido Laborista en el "nuevo" Partido Laborista de Blair y Brown ${ }^{41}$. Pinochet (si hubiese tenido capacidad para articular su pensamiento), habría podido decir lo mismo de la "nueva" izquierda en Chile. Son buenos ejemplos de cómo los neoliberales lograron "fabricar

\footnotetext{
40 Para obtener más información sobre cómo la "nueva" izquierda latinoamericana ha perdido su compás ideológico, véase Palma (2016b).

${ }^{41}$ Véase [en línea] https://www.independent.co.uk/news/uk/politics/margaret-thatcher-s-legacy-spilt-milk-new-labour-and-bigbang-she-changed-everything-8564541.html.
} 
consentimiento" en el sentido ya citado de Chomsky. Como nos recuerda Žižek (2008), el signo más revelador del éxito neoliberal al respecto, particularmente en la esfera económica, fue cuando la "nueva" izquierda comenzó "a contar historias de los demás como si fueran propias".

Parte de esta estrategia fue contar dichas historias, disfrazadas de "tercera vía", tanto a sus bases, como a la élite capitalista y a los mercados financieros internacionales. Así también justificaba su reacia aceptación inicial del modelo neoliberal. Lo más sorprendente de esto fue la facilidad con la que esta narrativa convenció a los propios narradores. 


\section{Anexo A2}

\section{La socialdemocracia de posguerra frente a la "tercera vía" posterior a Thatcher y Reagan}

En el pensamiento socialdemócrata posterior a la Segunda Guerra, e incluso antes de su final (como en la reunión de Bretton Woods), hubo una idea clave: la única manera eficaz de salir del desastre era "reestructurar para reactivar". Esta misma idea es la más relevante para la situación actual de América Latina (Palma, 2020a). Esta noción exigía una nueva agenda económica y social que estuviesen estrechamente interrelacionadas y reforzadas mediante la interacción. La simetría entre las dos agendas en la posguerra se convirtió en el distintivo de esta estrategia, y uno de sus principales puntos fuertes. En cambio, la asimetría entre las dos se convirtió en el rasgo definitorio y la mayor debilidad de la "versión 2.0" de esta estrategia en la Europa neoliberal posterior a la década de los ochenta. La agenda económica iba en una dirección y la agenda social, en otra.

\section{Las contracorrientes neoliberales de la década de los setenta}

Una forma de concebir el resurgimiento del neoliberalismo durante la década de los setenta es que la estanflación posterior a 1973 despertó el poder destructivo del fundamentalismo; quienes veneraban las fuerzas del mercado desregulado soñaban con una oportunidad para vengarse del éxito de la "herejía" rooseveltiano-keynesiana. Lo que los neoliberales realmente temían era que ese éxito destruyese la fe en los mercados libres, y amenazara con un caos analítico que acabaría con la comprensión y eliminaría el significado.

Este miedo puso en juego instintos destructivos, ya que la peor parte de la "herejía" rooseveltianokeynesiana (y del estructuralismo en la periferia) fue su indiscutible éxito en la reestructuración y reactivación de la economía mundial después de la guerra, tanto al norte como al sur del ecuador.

Por lo tanto, el verdadero desafío para los neoliberales no era superar creativamente el keynesianismo, sino erradicarlo de la faz de la tierra. Cuando se le preguntó al principal ideólogo de las reformas neoliberales del Brasil cuál era su principal objetivo, respondió que era "deshacer 40 años de estupidez", agregando que para entonces uno era o bien neoliberal o bien "neoidiota" (Revista Veja, 15 de abril de 1998). Esta idea de deshacer estupideces (de multiplicarlo todo por -1) fue lo que hizo que estas reformas neoliberales se convirtieran en un ejercicio de destrucción no creativa.

Según el psicoanalista Ron Britton (1998), existe una relación directa entre la expectativa de entender la realidad y la tolerancia con la discrepancia. Cuanto más altas son las expectativas (como suele ser en las ciencias naturales), mayor es la tolerancia a la discrepancia; pero si las expectativas son bajas, la intolerancia suele ser alta. La disciplina económica posreformas neoliberales es un ejemplo paradigmático de esto último.

La concepción de Foucault (2009) de la relación entre el poder y el conocimiento, en particular, el rol de la disciplina económica en la democracia - como una forma de poder que disciplina imponiendo formas específicas de conocimiento - , es útil para comprender la función de los "expertos" en todo esto. En Chile, y en todo el mundo, muchos se han convertido en la guardia pretoriana del neoliberalismo. En un debate reciente en Chile sobre el retiro del $10 \%$ de los fondos de pensiones privados para ayudar a los hogares a paliar la disminución de los ingresos provocada por la pandemia, los autodenominados "expertos" compitieron entre sí para ver quién hacía la predicción más apocalíptica de lo que sucedería si el Parlamento lo aprobaba. Sin embargo, como hacía tiempo que gritaban que venía el lobo, ahora nadie les prestó mucha atención. 


\section{La asimetría cada vez mayor entre la agenda económica y la social en la nueva socialdemocracia europea}

El problema fundamental de la nueva socialdemocracia europea, a diferencia de su versión de posguerra, es que su nueva agenda económica se ha disociado por completo de su agenda social (la cual sigue su formulación tradicional). La primera absorbió indiscriminadamente el discurso económico neoliberal, mientras que la segunda se declaró inmune a esto.

Además, como ambas agendas permanecen ancladas en el pasado -una, (la social) intenta repetirlo: la otra (la económica) intenta lo opuesto (construir un futuro que es el opuesto a dicho pasado)-, ignoran que la nueva revolución tecnológica y el nuevo orden económico internacional obligan a replantearse todo de modo creativo. El epítome de esta asimetría es Alemania, como se refleja claramente en su distribución mercado.

Gráfico A2.1

Alemania y Chile: desigualdad mercado según el índice de Gini, 1960-2017

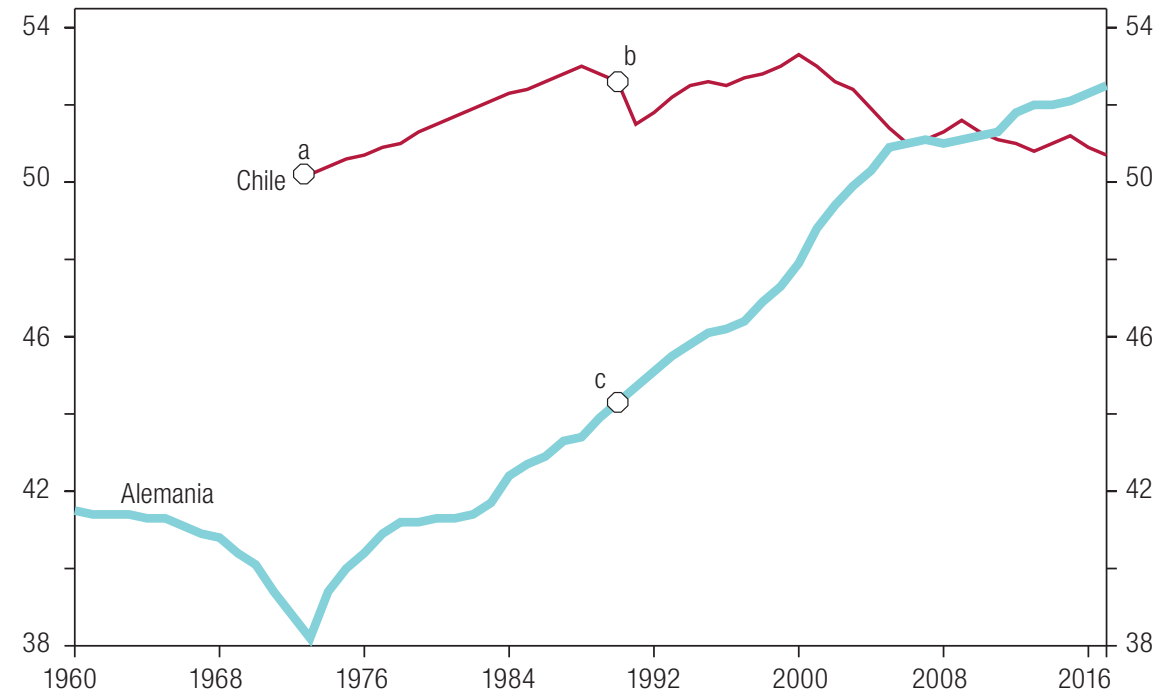

Fuente: Standardized World Income Inequality Database, octubre de 2020 [en línea] https://fsolt.org/swiid/.

Nota: Como la fuente no proporciona información por deciles, no es posible realizar el análisis usando el coeficiente de Palma.

a. Golpe de Estado de Pinochet.

b. Retorno de Chile a la democracia.

c. Reunificación alemana.

Es sorprendente cómo la elección de Ronald Reagan y Margaret Thatcher y la caída del Muro de Berlín embarcaron a los países de la OCDE en un proceso de cerrar brechas "al revés" con respecto a países de ingreso medio altamente desiguales, como América Latina, "bananizando" su desigualdad mercado. El Consenso de Washington prometió la convergencia en todo el mundo, y no solo en los ingresos, sino también en las instituciones y la desigualdad. Aunque en lo distributivo (y más) se produjo dicha convergencia distributiva, esta, como indica el gráfico A2.1, jocurrió en la dirección equivocada!

La diferencia entre la agenda económica socialdemócrata de la posguerra en Europa y los Estados Unidos y la posterior agenda neoliberal es que la primera intentaba generar un dinamismo económico "disciplinando" el capital, mientras que esta última inculcó en el "sentido común" (perspectiva de Gramsci) que la única forma de generar crecimiento económico era manteniendo a los ricos contentos. 
Como se muestra en el gráfico A2.1, esto tuvo un impacto desigualador en la distribución del ingreso mercado (antes de impuestos y transferencias) previamente inimaginable.

Además, mientras que en Alemania el índice de Gini de mercado aumentó un tercio, la inversión cayó en la misma medida, del 30\% del PIB al 20\%, acercándola al promedio de América Latina desde 1980. Esta obsesión por "latinoamericanizar" la inversión se generalizó en los países de la OCDE. Mientras tanto, el crecimiento de la productividad en Alemania también disminuyó de aproximadamente el 4\%-5\% anual a casi cero, de nuevo, similar al promedio latinoamericano desde 1980 (Palma, 2019a y 2020b).

Por lo tanto, en cuanto a la desigualdad, la nueva ley de hierro de la oligarquía parece indicar que, con la desigualdad mercado inflada artificialmente al estilo latinoamericano, cuanto mayor es la proporción del ingreso que se apropian los más ricos, menor es la proporción de ese ingreso que se devuelve a la economía de forma productiva. Como ya se sugirió, es tentador decir "bienvenidos al tercer mundo".

Los Estados Unidos también se volvieron más desiguales en su distribución mercado que su vecino al otro lado del Río Grande (índices de Gini de 51 para los Estados Unidos y de 47 para México en 2018). Si los Estados Unidos tuvieran el mismo nivel de ingresos que tenían antes de la pandemia, pero la desigualdad de cuando Reagan fue elegido Presidente, el 1\% más rico ganaría 2 billones de dólares menos de lo que ganaba (una cifra superior al PIB del Brasil). Mientras tanto, el salario medio real por hora ha estado estancado desde Reagan.

A su vez, si los Estados Unidos tuvieran los mismos ingresos y la misma desigualdad que tenían en 2019, pero su proporción de inversión con respecto al PIB fuera como antes de Reagan, se invertiría más de 1 billón de dólares más al año. Al vincular ambos indicadores (mayor desigualdad con menor inversión y crecimiento de la productividad), encontramos un clara tendencia "bananizadora"; esto es, a cerrar la brecha "al revés" (reverse catching up) con respecto a la forma que operan los países al otro lado del río Grande.

Así pues, no debería sorprendernos que cuando el Papa Francisco se refirió a este tipo de capitalismo, y su avaricia descontrolada, dijera que es el "estiércol del diablo", la cual crea una "dictadura sutil" y saquea la naturaleza ${ }^{42}$. Además, al hablar de los mercados financieros, añadió que "se instaura una nueva tiranía invisible, a veces virtual, que impone, de forma unilateral e implacable, sus leyes y sus reglas" 43 .

Mi crítica principal a la "nueva" socialdemocracia europea no es que se neoliberalizó (sobre gustos no hay nada escrito); es sobre su inhabilidad de absorber elementos del neoliberalismo económico en forma creativa. Como decíamos, para Gramsci (2000) todas las ideologías hegemónicas, de querer seguir siéndolo, tienen que absorber elementos de ideologías opuestas, articulándolos con la esencia de su propia ideología. Esto significa que para que un consenso siga siendo hegemónico, los grupos dominantes tienen que hacer concesiones ideológicas con respecto a los grupos subordinados, pero sin poner en peligro su dominio. Eso es lo que ha hecho tan bien la élite de Chile después de perder el plebiscito de 1988 y el retorno a la democracia, y está intentando hacerlo de nuevo en lo que el artículo del que forma parte este anexo denomina estrategia 4, integrando aspectos de la agenda social de la "nueva" socialdemocracia europea (como la necesidad de protección social), mientras mantiene intacta su agenda económica en el "más de lo mismo".

Lo más atrayente de la "nueva" socialdemocracia europea para ellos, es que hizo este esfuerzo de absorber elementos de la ideología opuesta con poca imaginación y, a veces, de modo oportunista, y permitió que la ideología económica neoliberal simplemente sustituyera a la propia. El resultado fue una ideología económica insípida y totalmente disociada de la agenda social.

\footnotetext{
42 Véase [en línea] https://edition.cnn.com/2015/07/07/world/pope-mass-ecuador-quito/index.html; y https://www.theguardian. com/world/2015/jul/10/poor-must-change-new-colonialism-of-economic-order-says-pope-francis.

${ }^{43}$ Véase [en línea] https://uk.reuters.com/article/pope-economy/pope-rails-against-dictatorship-of-the-economy-urges-reformidUSL6NODX27N20130516.
} 
La cuestión fundamental es que el sorprendente deterioro de la desigualdad mercado de Alemania distaba mucho de ser inevitable (igual que en el resto de Europa, Occidental y Oriental). En el gráfico A2.2 se compara Alemania y la República de Corea.

Gráfico A2.2

Alemania y la República de Corea: desigualdad mercado y desigualdad ingresos disponibles, 1960-2016
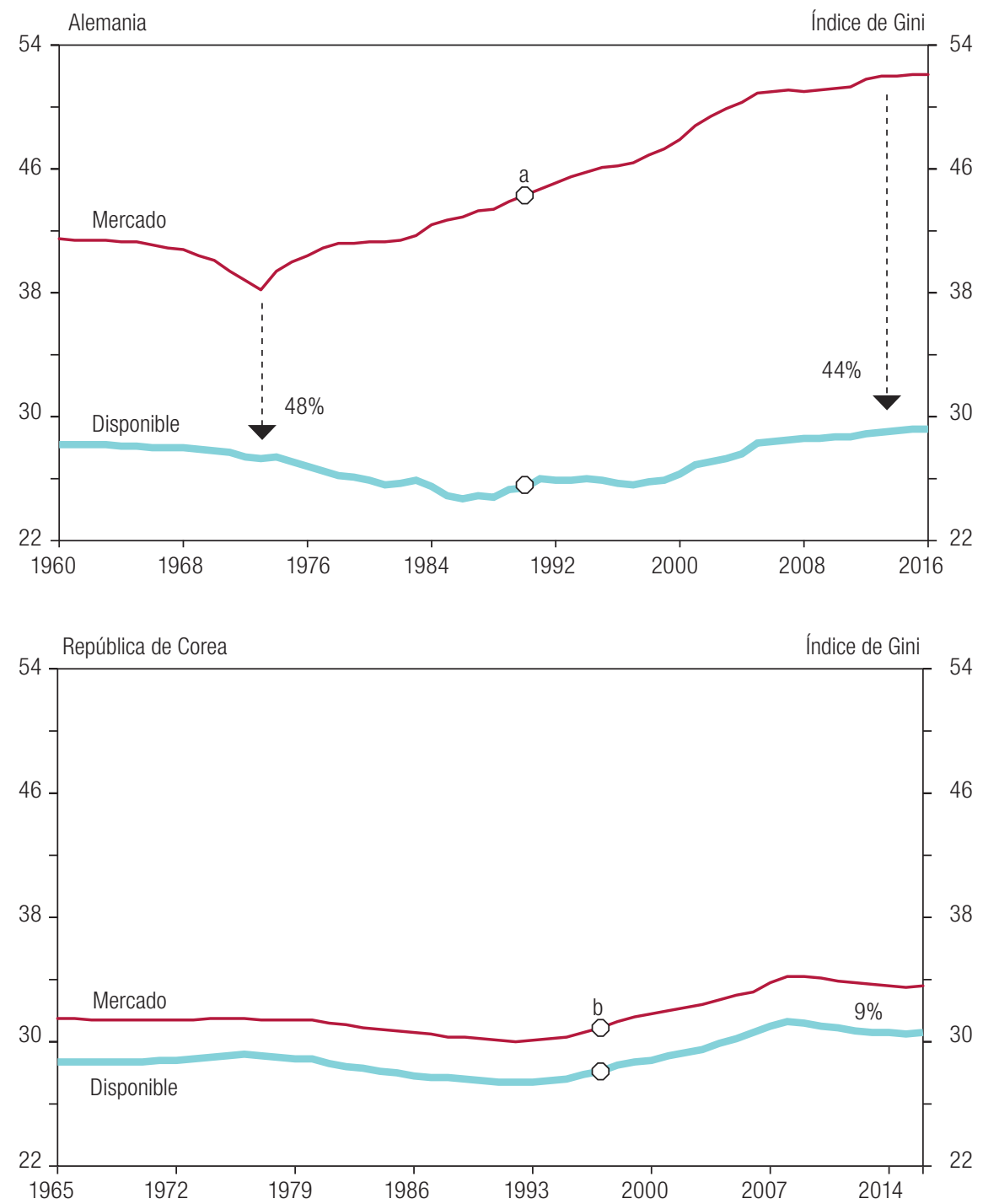

Fuente: Standardized World Income Inequality Database, octubre de 2020 [en línea] https://fsolt.org/swiid/.

Nota: a. Reunificación alemana.

b. Crisis financiera.

Como se muestra en el gráfico A2.2, Alemania y la República de Corea llegaron a una distribución similar en sus ingresos disponibles (un índice de Gini de alrededor de 30; equivalente a un índice de Palma de aproximadamente 1,2). Sin embargo, la República de Corea ya casi alcanza ese bajo nivel de desigualdad de ingresos disponibles en el ámbito de la producción. Alemania, en cambio, ha elegido seguir un camino tortuoso: mientras deja que su distribución mercado empeorase artificialmente 14 puntos porcentuales en la escala de Gini entre mediados de la década de 1970 y mediados de 
la década de 2010, luego (y a diferencia de los países de América Latina) pone en marcha una política redistributiva de proporciones faraónicas para llegar al mismo nivel de desigualdad en los ingresos disponibles que la República de Corea (país que alcanza ese bajo nivel de desigualdad sin mucho esfuerzo de redistribución, porque casi lo consigue en el mercado).

Eso es lo que llamo la "falla distributiva" de la nueva socialdemocracia europea (Palma, 2019a). Dejar que las cosas vayan por un lado en el mercado, para luego revertirlas con impuesto y transferencias. Esta falla es diferente a un aumento autoconstruido de la desigualdad mercado per se, lo cual es una falla distributiva en sí mismo. Esta nueva falla distributiva está vinculada a la necesidad de tener que hacer un esfuerzo cada vez mayor para poder reducir la crecientemente distorsionada desigualdad mercado, lo cual absorbe cada vez más recursos y ciertamente es insostenible a largo plazo (Palma, 2019a).

El resultado de esta falla distributiva es que los requisitos directos de protección social en la Unión Europea ya representaban el $40 \%$ del gasto público antes de la pandemia, o un equivalente al $16 \%$ del PIB. Si se le suma la salud y la educación pública, los tres ámbitos juntos representaban dos tercios de todo el gasto público o una cantidad equivalente al 25\% del PIB. Y a consecuencia de la pandemia, como la desigualdad y la necesidad de protección social han aumentado, este coste se ha disparado ${ }^{44}$. En la zona del euro, por ejemplo, el déficit presupuestario se ha multiplicado casi por diez para contrarrestar la pandemia (Financial Times, 2020b).

En resumen, incluso antes de la pandemia, en Alemania uno de cada cuatro euros de valor agregado tenía que destinarse a los diferentes aspectos de la protección social, principalmente para corregir una desigualdad mercado autoconstruida, innecesaria, ineficiente y gigantesca -incluso similar a la latinoamericana-.

El Papa Francisco da en el clavo cuando aborda este tema: "Cierto liberalismo cree que es necesario producir primero riqueza [para unos pocos], no importa cómo, para después promover alguna política redistributiva por parte del Estado" (Librería Editrice Vaticana, 2015). La clave aquí es el "no importa cómo": Europa no solo ha "latinoamericanizado" su desigualdad mercado, sino que su élite cada vez más financierizada y rentista, al hacer esto, ha hecho lo mismo con los niveles de inversión y crecimiento de la productividad.

Mientras tanto, la República de Corea solo necesita invertir el 11\% del PIB en protección social para alcanzar la misma distribución del ingreso disponible para la que Alemania tiene que gastar más del doble. Por eso la República de Corea puede permitirse dos lujos simultáneamente: recaudar 15 puntos porcentuales del PIB menos en impuestos que Alemania y tener un nivel de inversión pública que es el doble del de Alemania (OCDE, 2020a).

Debido a esto, el nuevo estado del bienestar socialdemócrata europeo ha terminado siendo un subsidio de facto para la desigualdad mercado, ya que una desigualdad tan alta no sería políticamente viable sin un nivel estratosférico de protección social, el cual requiere un nivel de impuestos por sobre el 40\% del PIB y una explosión de la deuda pública. La protección social es, supuestamente, un subsidio para los más pobres, pero en la práctica, uno de los mayores beneficiarios son los grupos de ingresos altos pues les permite continuar con el "más de lo mismo".

Esto también se refleja en que después de la crisis financiera mundial de 2008, los Estados Unidos y Europa gastaron 1 billón de dólares en rescates bancarios e inyectaron 15 billones de dólares a través de la flexibilización cuantitativa (QE), que ha aumentado enormemente, y en forma artificial, el patrimonio neto de un pequeño grupo de personas (Palma, 2020b). El resultado, como ya se dijo, es que el estado de bienestar se ha transformado de facto en un Robin Hood posmoderno, que "roba" a los ricos para darles a los más ricos (Palma, 2020c).

44 Véanse Financial Times (2020a) y Palma (2020b). 